ENGINEERING CHANGE NOTICE

1. ECN 629415 Pago 1 of 2 Proj.

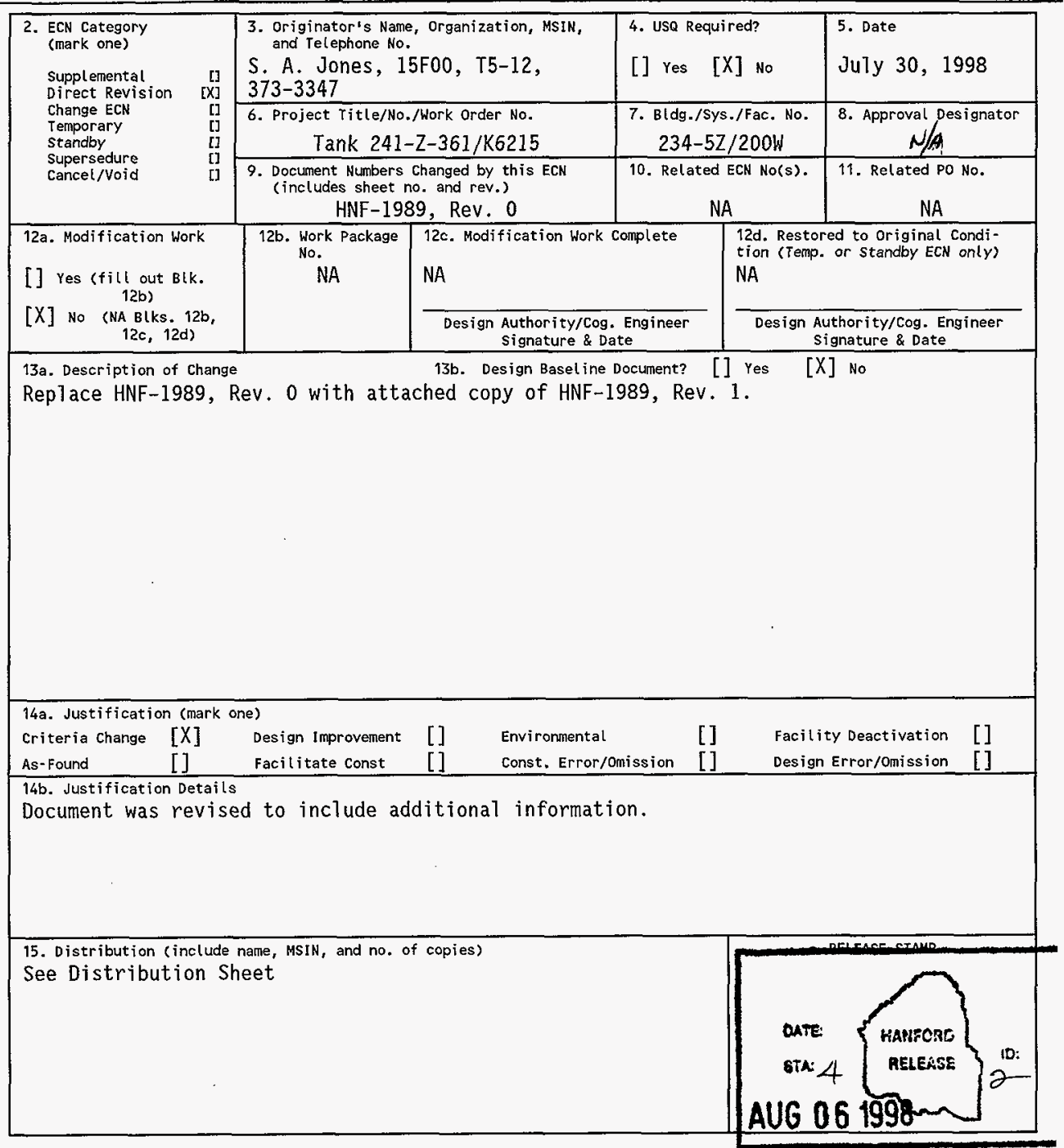




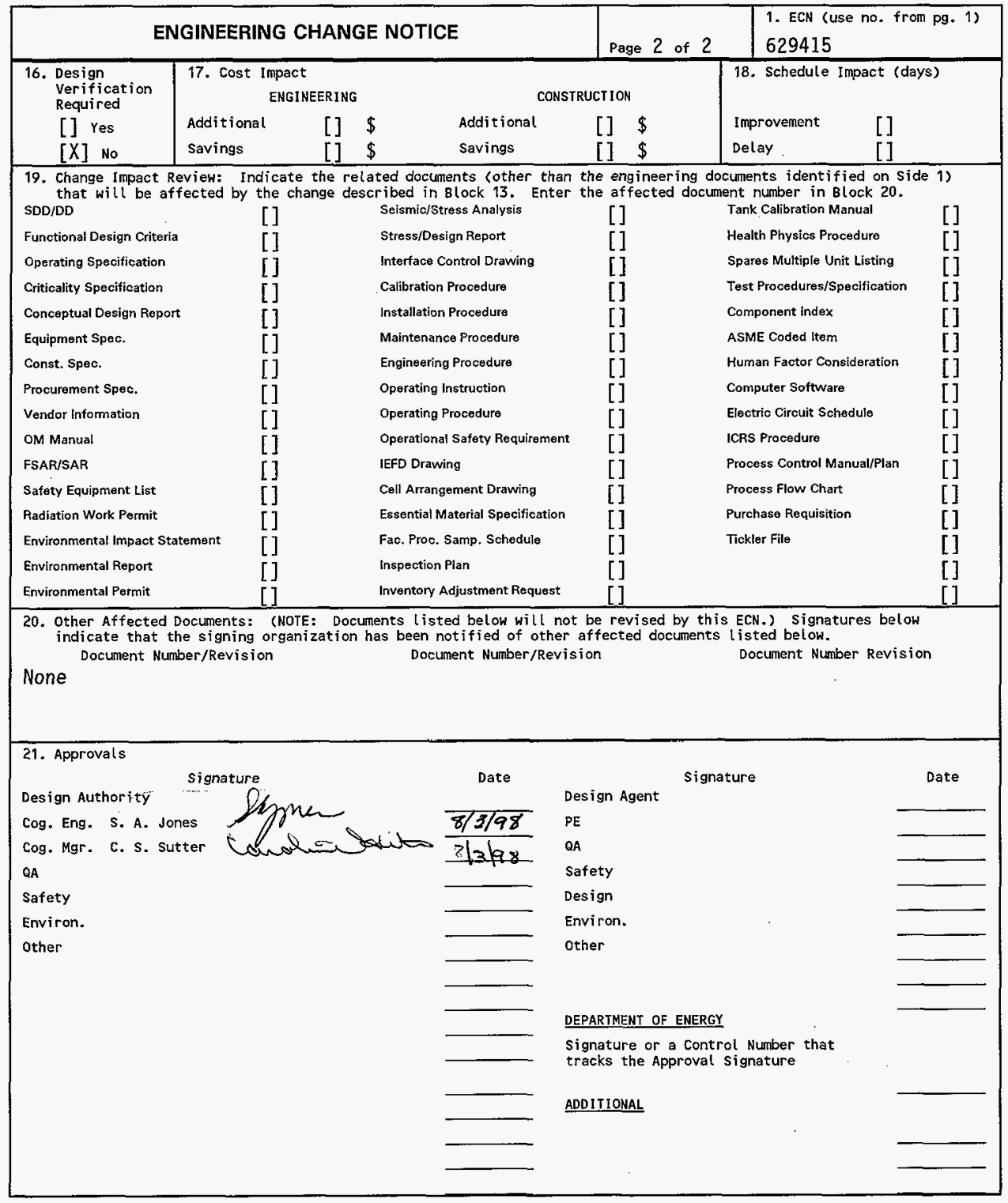




\title{
Tank 241-Z-361 Process and Characterization History
}

\author{
S. A. Jones \\ B\&W Hanford Company, Richland, WA 99352 \\ U.S. Department of Energy Contract DE-AC06-96RL13200 \\ EDT/ECN: $609890 \mathrm{~km} / 2 \mathrm{~L} / \mathrm{UC}$ : \\ Org Code: 15F00 $32 / 98$ Charge Code: K6215 \\ B\&R Code: 3120074 Total Pages:55
}

Key Words: 241-Z-361, settling tank, plutonium, PFP, process history

Abstract: The history of the Plutonium Finishing Plant processes that sent waste to Tank 241-Z-361 is summarized. Documents reviewed include engineering files, laboratory notebooks from characterization efforts, and interviews of people. Records of transfers to the tank, past characterization efforts, and speculation were used to estimate the current condition of Tank $241-2-361$ and its contents.

TRADEMARK DISCLAIMER. Reference herein to any specific comercial product, process, or service by trade name, trademark, manufacturer, or otherwise, does not necessarily constitute or imply its endorsement, recommendation, or favoring by the United states Government or any agency thereof or its contractors or subcontractors.

Printed in the United States of America, To obtain copies of this document, contact: Document Control Services, P.O. Box 950, Maillstop H6-08, Richland WA 99352, Phone (509) 372-2420; Fa (509) 376-4989.
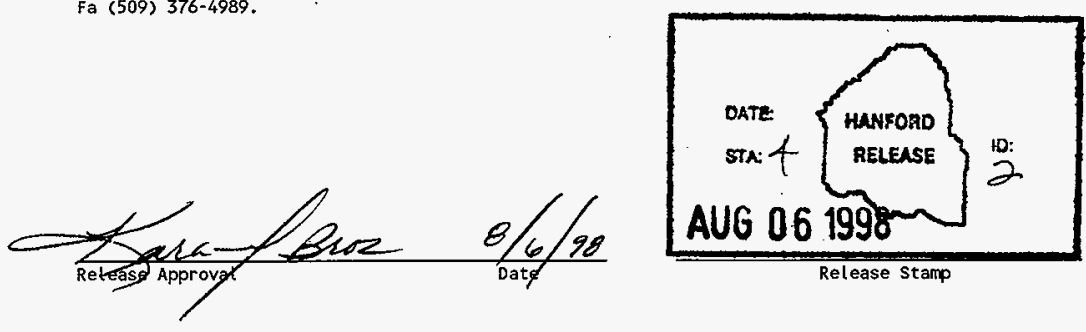

Release Stamp

Approved for Public Release 


\section{RECORD OF REVISION}

(1) Document Number

HNF-1989

(2) Title

Tank 241-2-361 Process and Characterization History

CHANGE CONTROL RECORD

\begin{tabular}{|c|c|c|c|c|}
\hline \multirow{2}{*}{ (3) } & \multirow{2}{*}{ Revision } & \multirow{2}{*}{ (4) Description of Change - Replace, Add, and Delete Pages } & \multicolumn{2}{|c|}{ Authorized for Release } \\
\hline & & & (5) Cog. Engr. & (6) Cog. Mgr. \\
\hline & 0 & $\begin{array}{l}\text { (7) EDT 609890, December 23, } 1997 \text { (Initial } \\
\text { Issue) }\end{array}$ & & \\
\hline & $1 \mathrm{RS}$ & $\begin{array}{l}\text { Revised to include additional data and } \\
\text { information } E C N-629415\end{array}$ & SAPlones & 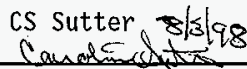 \\
\hline & & & & \\
\hline & & & & \\
\hline & & & & \\
\hline & & & & \\
\hline & & & & \\
\hline & & & & \\
\hline & & & & \\
\hline & & & & \\
\hline & & & & \\
\hline & & & & \\
\hline & & & & \\
\hline & & & & \\
\hline & & & & \\
\hline & & & & \\
\hline & & & & \\
\hline & & & & \\
\hline & & & & \\
\hline & & & & \\
\hline & & & & \\
\hline & & & & \\
\hline & & & & \\
\hline & & & & \\
\hline & & & & \\
\hline & & & & \\
\hline & & & & \\
\hline & & & & \\
\hline & & & & \\
\hline & & & & \\
\hline & & & & : \\
\hline & & & & \\
\hline & & & & \\
\hline & & & & \\
\hline
\end{tabular}




\title{
TANK 241-Z-361 PROCESS AND CHARACTERIZATION HISTORY
}

\author{
S. A. Jones
}

\section{INTRODUCTION}

An Unreviewed Safety Question (Wagoner, 1997) was declared based on lack of adequate authorization basis for Tank 241-Z-361 in the 200W Area at Hanford. This document is a summary of the history of Tank 241-Z-361 through December 1997. Documents reviewed include engineering files, laboratory notebooks from characterization efforts, waste facility process procedures, supporting documents and interviews of people's recollections of over twenty years ago. Records of transfers into the tank, past characterization efforts, and speculation were used to estimate the current condition of Tank 241-Z-361 and its contents. Information about the overall waste system as related to the settling tank was included to for help in understanding the numbering system and process relationships.

The Plutonium Finishing Plant was built in 1948 and began processing plutonium in mid1949. The Incinerator (232-Z) operated from December 1961 until May 1973. The Plutonium Reclamation Facility (PRF, 236-Z) began operation in May 1964. The Waste Treatment Facility (242-Z) (Kasper, 1980) operated from August 1964 until August 1976. Waste from some processes went through transfer lines to $241-Z$ sump tanks. High salt and organic waste under normal operation were sent to Z-9 or Z-18 crib. Water from the retention basin may have also passed through this tank.

The transfer lines to $241-Z$ were numbered $D-4$ to $D-6$. The $241-Z$ sump tanks were numbered D-4 through D-8. The D-4, 5, and 6 drains went to the D-6 sump tank. When D-6 tank was full it was transferred to D-7 tank. Prior to transfer to cribs, the D-7 tank contents was sampled. If the plutonium content was analyzed to be more than $10 \mathrm{~g}$ per batch, the material was (generally) reprocessed. Below the discard limit, caustic was added and the material was sent to the cribs via the 241-Z-361 settling tank where solids settled out and the liquid overflowed by gravity to the cribs.

Waste liquids that passed through the 241-Z-361 settling tank flowed from PFP to ground in the following sequence:

$$
\begin{gathered}
\text { Processes } \rightarrow \text { D-4, D-5, D-6 Drains } \rightarrow \text { D-6 Sump Tank } \rightarrow \text { D-7 or D-8 Sump Tank } \rightarrow \text { 241-Z- } \\
\quad 361 \text { Settling Tank } \rightarrow \text { Cribs }
\end{gathered}
$$

Each is discussed below. In addition, samples taken of the settling tank sludge and analyzed in the mid-1970s are evaluated.

\section{PROCESSES}

"Low-salt" waste passing through $241-Z-361$ consisted of large volumes of water containing 
relatively low concentrations of chemicals compared to the "high-salt" waste transferred to Z-9 or Z-18. Process streams contributing to the low-salt waste are listed in Table 1.

Table 1. Low-salt Aqueous Process Streams in the Plutonium Finishing Plant

\begin{tabular}{|l|l|l|l|l|}
\hline Stream & Source & $\begin{array}{l}\text { Thousands of } \\
\text { Gallons/Year }\end{array}$ & $\begin{array}{l}\text { Plutonium } \\
\text { Grams/Year }\end{array}$ & $\begin{array}{l}\text { Chemical } \\
\text { Contaminant }\end{array}$ \\
\hline $\begin{array}{l}\text { Uncontaminated } \\
\text { lab wastes }\end{array}$ & $\begin{array}{l}\text { Cooling } \\
\text { equipment in } \\
\text { labs }\end{array}$ & 127 & 0 & None \\
\hline $\begin{array}{l}\text { Contaminated } \\
\text { lab wastes }\end{array}$ & $\begin{array}{l}\text { Lab sink } \\
\text { drains }\end{array}$ & 174 & 100 & $\begin{array}{l}\text { Miscellaneous lab } \\
\text { chemicals }\end{array}$ \\
\hline $\begin{array}{l}\text { Waste treatment } \\
\text { aqueous waste }\end{array}$ & lon exchange & 86 & 60 & $\begin{array}{l}\text { Principally Al, Ca, } \\
\text { Mg, nitrate }\end{array}$ \\
\hline $\begin{array}{l}\text { Incinerator } \\
\text { scrubber } \\
\text { solution }\end{array}$ & $\begin{array}{l}\text { Spent caustic } \\
\text { from scrubber }\end{array}$ & 6 & 600 & Considerable $\mathrm{Na}$ \\
\hline $\begin{array}{l}\text { Reclamation } \\
\text { condensate }\end{array}$ & $\begin{array}{l}\text { Process } \\
\text { concentrators }\end{array}$ & 54 & 12 & Slight \\
\hline $\begin{array}{l}\text { Fluorinator off- } \\
\text { gas jet }\end{array}$ & $\begin{array}{l}\text { Water for } \\
\text { vacuum jet }\end{array}$ & 1906 & 100 & hydrogen fluoride \\
\hline total & & 2353 & 872 & \\
\hline
\end{tabular}

Cooling water was simply sanitary water in closed lines that did not come in contact with chemicals or radioactive material.

Laboratory wastes constituted a very small portion of the total volume of wastes. While there may have been almost anything in that waste stream and there is virtually no information about it, the small volume coupled with large dilutions with the process streams make it unlikely to contain enough material to be of concern.

Aluminum nitrate was added during waste treatment for plutonium recovry in PRF to complex fluoride in the waste. The amount varied depending upon the feed that was sand, slag, and crucible (SS\&C) from RMC processing, assorted feeds, and CAW rework. Calcium, magnesium, and iodine also originated in the SS\&C.

The incinerator burned a variety of materials including organic chemicals, paper and plastic. A caustic off-gas scrub solution was used to trap acid fumes, combustion products and fine particles. The incinerator operated intermittently from December 1961 to May 1973. In 1969, it was estimated that 600 grams of the 870 grams of plutonium sent to Z-12 were from the incinerator.

There is little known about reclamation condensate except that the chemical contaminants were considered "slight".

Fluorinator off-gas from hood $\mathrm{HC}-9 \mathrm{~B}$ on the "Button Lines" contributed the largest 
volume of waste to D-6. It was also responsible for failure of D-6 due to corrosion. The HF concentration was approximately $0.06 \mathrm{M}$.

An estimate of the chemicals in the low salt waste from all sources in 1969 is given in Table 2. The process waste streams from $236-Z$ and $234-5 Z$ to $241-Z$ were documented in 1990 (Barrington). As can be seen in

Table 3, the concentrations of some constituents are quite high. The low-salt designation is

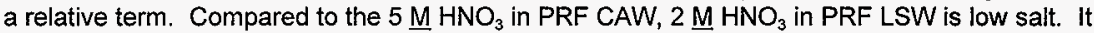
should be noted also that these were concentrations from streams prior to blending and treatment at the 241-Z Waste Treatment Facility. Although this 1990 memo was written long after Tank 241-Z-361 was inactivated, the chemistry of the processes had not changed, only the final disposition of the waste.

Table 2. Process chemicals discharged to low-salt waste in 1969.

\begin{tabular}{|l|l|l|l|}
\hline Chemical & Weightyear & Chemical & Weight/year \\
\hline Plutonium & $870 \mathrm{~g}$ & Aluminum & $96 \mathrm{~kg}$ \\
\hline Calcium & $320 \mathrm{~kg}$ & Sodium & $7,394 \mathrm{~kg}$ \\
\hline Magnesium & $128 \mathrm{~kg}$ & Fluoride & $6,100 \mathrm{~kg}$ \\
\hline Manganese & $13 \mathrm{~kg}$ & Nitrate & $19,904 \mathrm{~kg}$ \\
\hline
\end{tabular}

Table 3. PFP Radioactive Effluent Stream Compositions

\begin{tabular}{|c|c|c|c|c|}
\hline \multicolumn{5}{|c|}{ PFP Radioactive Effluent stream Compositions } \\
\hline & Units & PRF LSW & RMC LSW & D\&AL LSW \\
\hline Normal Flow & I/hr & 43 & $\begin{array}{r}66 \\
\end{array}$ & 20 \\
\hline Peak Flow & $\mathrm{l} / \mathrm{hr}$ & 110 & 90 & 200 \\
\hline SpG & $\mathrm{g} / \mathrm{cc}$ & 1.06 & 1.03 & 1.01 \\
\hline Species & & \multicolumn{3}{|c|}{ Nominal Composition } \\
\hline $\mathrm{Al}$ & $M$ & 0 & 0 & 0 \\
\hline $\mathrm{Ba}$ & $\bar{M}$ & $4.40 E-06$ & $1.80 \mathrm{E}-06$ & $2.00 \mathrm{E}-07$ \\
\hline $\mathrm{Ca}$ & $M$ & 0.0001 & 0.00006 & 7.90E-06 \\
\hline $\mathrm{Cr}$ & $M$ & 2.00E-07 & 2.00E-07 & 2.00E-07 \\
\hline $\mathrm{Fe}$ & $M$ & 0.0002 & 0.00007 & 8.50E-06 \\
\hline $\mathrm{H+}$ & $\mathrm{M}$ & 2 & 0.8 & 0.1 \\
\hline $\mathrm{K}+$ & $M$ & 0.005 & 0.0003 & 0 \\
\hline $\mathrm{Mg}++$ & $M$ & 0.000002 & 0.00001 & $1.30 \mathrm{E}-06$ \\
\hline $\mathrm{Mn++}$ & $M$ & 0.003 & 0.005 & 4.00E-07 \\
\hline $\mathrm{Na}+$ & $M$ & 0.006 & 0.005 & 0.004 \\
\hline $\mathrm{Ni++}$ & $\bar{M}$ & 2.00E-07 & $2.00 \mathrm{E}-07$ & $2.00 \mathrm{E}-07$ \\
\hline $\mathrm{Pb}++$ & $M$ & 0 & 0 & 0 \\
\hline $\mathrm{Sr}++$ & $\bar{M}$ & $1.70 \mathrm{E}-06$ & 7.00E-07 & $9.00 \mathrm{E}-08$ \\
\hline
\end{tabular}


Table 4. PFP Radioactive Effluent Stream Compositions (cont.)

\begin{tabular}{|c|c|c|c|c|}
\hline Species & & \multicolumn{3}{|c|}{ Nominal Composition } \\
\hline & Units & PRF LSW & RMC LSW & D\&AL LSW \\
\hline $\mathrm{OH}-$ & $M$ & 0 & 0 & 0 \\
\hline $\mathrm{CO}-$ & $\bar{M}$ & 0 & 0 & 0 \\
\hline $\mathrm{Cl}-$ & $M$ & 0.006 & 0.001 & 0.0003 \\
\hline F- & $\bar{M}$ & 0 & 0 & 0 \\
\hline $1-$ & $\mathrm{M}$ & 0 & 0 & 0 \\
\hline NO3- & $\bar{M}$ & 2 & 0.8 & 0.02 \\
\hline NO2- & $\bar{M}$ & 0.01 & 0.01 & 0.0003 \\
\hline PO4-- & $M$ & 0.00009 & 0.00004 & $5.00 \mathrm{E}-06$ \\
\hline SO4-- & $\bar{M}$ & 0 & 0 & 0 \\
\hline CCL4 & $\mathrm{M}$ & 0.002 & 0 & 0 \\
\hline Ammonia & $\bar{M}$ & 0 & 0 & 0 \\
\hline TBP & $\bar{M}$ & 0 & 0 & 0 \\
\hline Butanol & $\bar{M}$ & 0.008 & 0 & 0 \\
\hline DBP & $M$ & 0 & 0 & 0 \\
\hline MBP & $M$ & 0 & 0 & 0 \\
\hline TOC & $g / 1$ & 0.4 & 0 & 0 \\
\hline Silica & $g / /$ & & 0 & 0 \\
\hline $\mathrm{Pu}$ & $g / /$ & 0.003 & 0 & 0.00001 \\
\hline $\mathrm{Am}$ & $g / 1$ & 0.001 & 0 & 0.00001 \\
\hline $\mathrm{U}$ & $g / /$ & 0 & 0 & 0 \\
\hline
\end{tabular}

\section{DRAINS}

Drains that fed into the 241-Z Waste Treatment facility are listed in Table 5. The sump tanks have the same numbering system, but do not necessarily feed to the same location. When reading some of the old documentation, it was some times difficult to determine if the author was referring to a drain or sump tank. This may be one reason for some of the confusion that exists regarding the waste systems.

Table 5. Drains that fed into the D-6 tank in 241-Z (Rodgers 1991).

\begin{tabular}{|l|l|}
\hline Drain & Area serviced \\
\hline D-4 & Plutonium Chemistry Laboratory \\
\hline D-5 & Analytical Laboratory - including film washing \\
\hline D-6 & $232-$ Incinerator \\
\hline & $234-5$ Process - hood 9-B fluorinator off-gas \\
\hline & $236-Z$ PRF \\
\hline & $242-Z$ Waste treatment \\
\hline
\end{tabular}




\section{1-Z SUMP TANKS}

Neutralization of acid wastes was initially accomplished by addition of soda ash. Later sodium hydroxide was used to bring the $\mathrm{pH}$ up to 10. Still later it was found that a $\mathrm{pH}$ of 8 was better for immobilizing $\mathrm{Pu}$ in soil (Rhodes) and the waste process was changed accordingly. Kasper stated in RHO-ST-44 "Occasionally, the wastes were only partially neutralized and were discharged slightly acidic."

Procedures in the waste treatment facility manual called for addition of caustic to the D-7 tank, checking with alkoacid paper. If the paper was still red, more caustic was added. If the paper turned blue, tank contents were jetted to the settling tank and crib. In 1962, the sump tanks were assayed for plutonium hold up. The D-7 tank contained approximately $300 \mathrm{~g}$ of plutonium, which was removed by flushing the tank with nitric acid coupled with some mechanical scraping. Apparently, the acid flushes were sent directly to the settling tank. This may account for one observation that the sludge was acidic (Lundgren).

\section{1-Z-361 SETTLING TANK}

The $241-Z-361$ settling tank is $13^{\prime}$ by $26^{\prime}$ rectangular structure that is $17^{\prime}$ deep at the influent end and 18' deep at the effiuent end. A cross-section view of the tank is shown in Figure 1. Liquid entered 241-Z-361 through a baffled opening on the north end of the tank. The overflow to the cribs is at the south end at the $15^{\prime}$ depth. The tank was constructed with 12" thick concrete walls, a layer of waterproofing, and a 3/8" thick carbon steel liner. Removal of all but about 800 liters of the supernate was completed May 1975. Photographs of the tank taken in 1975 showed that in the lower half of the tank the steel liner appears to have been corroded away with the waterproofing and concrete visible. This will contribute to the chemistry of the tank by adding iron from the dissolved liner. In addition, any concrete that reacts with the tank contents will raise the $\mathrm{pH}$ of acidic sludge. There has been much speculation as to the effect of the sludge on the structural integrity of the concrete and rebar in the tank. Scenarios have been proposed that range from the tank walls crumbling to the contents having a hardening effect on the concrete. The only certainty is that the tank condition will not be known until it is examined.

There are eight penetrations into the tank visible from above ground. In addition, underground there is a 4' cement in the center of the tank cover, a $3^{\prime}$ manhole at the north end, and a 3 ' manhole at the south end of the tank. These are illustrated in Figure 2. 
Figure 1. Side View Tank 241-Z-361

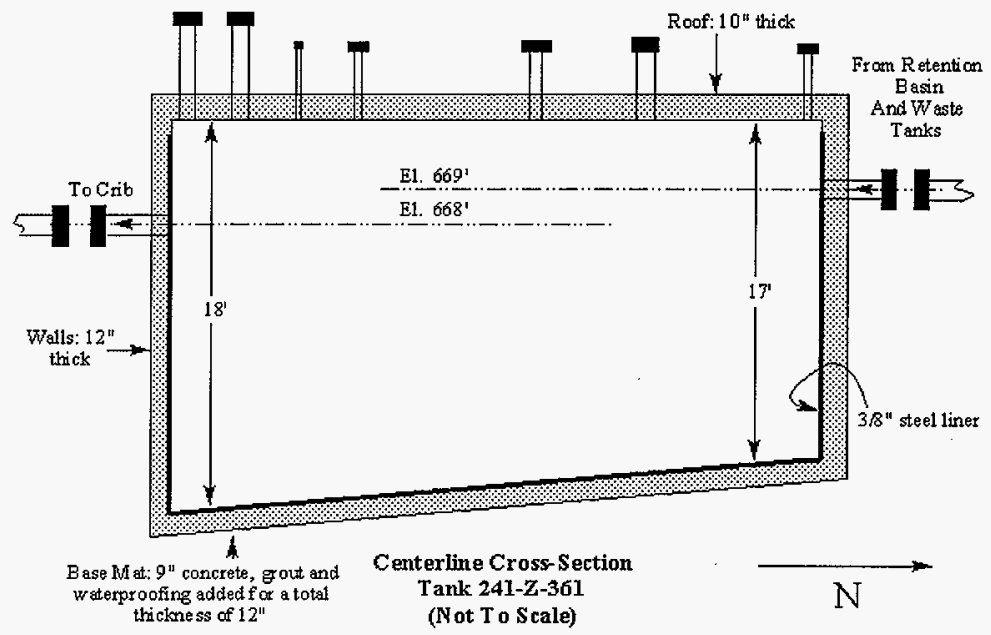

Figure 2. Top View 241-Z-361 Settling Tank.

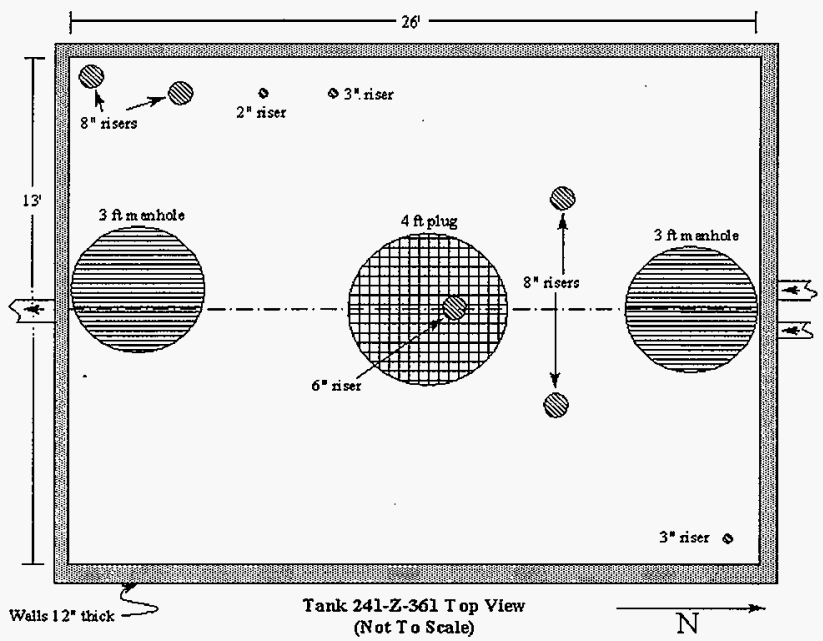


In March 1975, samples were taken through the north manhole. The liquid was analyzed as $0.0002 \mathrm{~g} / \mathrm{L} \mathrm{Pu}$ and $\mathrm{pH} 4$ at the 14'3" level, $0.0006 \mathrm{~g} / \mathrm{L} \mathrm{Pu}$ and $\mathrm{pH} 4$ at the $16^{\prime} 3^{\prime \prime}$ level, and sludge contained $0.91 \mathrm{~g} / \mathrm{L} \mathrm{Pu}$ and $\mathrm{pH}$ was very acid at the 18' $3^{\prime \prime}$ level (Lundgren). All measurements were from the top of the riser. The sampler rod stopped at the 18'3" level, possibly from hitting what remained of the corroded dry well. A sample request for differential thermal analysis of the samples was made, but no record of analysis results could be found.

There was an estimated 4000 gallons of supernate solution in the tank. Sodium hydroxide was added to the tank to bring the $\mathrm{pH}$ up to 12 for transfer to Tank Farms. After the caustic addition, the supernate was sampled and the $\mathrm{pH}$ was 6 . Buffering by hydrolyzable metal ions in solution must have been responsible for this lower than expected $\mathrm{pH}$. In May 1975, all but about 800 liters of liquid was pumped from the tank.

The sludge in the tank was sampled five times from 1975 to 1977 . The nonradioactive components that were analyzed are summarized in

Table 6.

Table 6. Average Nonradioactive Elements in 241-Z-361 Sludge.

\begin{tabular}{|r|r|r|}
\hline Chemical & Wt\% & Conc., g/L \\
\hline $\mathrm{Al}$ & 11.99 & 0.222 \\
\hline $\mathrm{Ca}$ & 18.11 & 0.335 \\
\hline $\mathrm{Cd}$ & 0.05 & 0.001 \\
\hline $\mathrm{Fe}$ & 12.50 & 0.232 \\
\hline $\mathrm{Na}$ & 3.59 & 0.066 \\
\hline $\mathrm{Si}$ & 0.45 & 0.008 \\
\hline $\mathrm{O}$ & 5.94 & 0.110 \\
\hline $\mathrm{H}$ & 1.64 & 0.030 \\
\hline $\mathrm{C}$ & 3.60 & 0.067 \\
\hline $\mathrm{Cl}$ & 1.85 & 0.034 \\
\hline $\mathrm{F}$ & 0.21 & 0.004 \\
\hline
\end{tabular}

The absolute concentrations of the nonradioactive species are suspect for the same reasons discussed later for plutonium concentration due to problems with the use of volume percent solids to calculate sludge concentrations. In addition, this matrix introduces significant interferences in the analytical method. Large deviations in sample concentrations were observed and these values should be used as a general indication of sludge composition only.

Carbon analysis results have not been found except for a few samples. The carbon concentration was as high as $6 \%$ by weight of the sample. This could be as carbon from fly ash in the incinerator scrubber solution, carbonate from neutralization and absorption in to caustic solution, or from organic compounds. Most likely it is from a combination of all of these sources. 
The bulk of the plutonium processed was weapons grade with an isotopic composition of approximately $93 \%{ }^{239} \mathrm{Pu}, 6 \%{ }^{240} \mathrm{Pu}$, and $0.6 \%{ }^{241} \mathrm{Pu}$. In the late 1960 's, limited processing of fuel elements from power reactors occurred. The plutonium recovered from this fuel had a different isotopic composition estimated at $55 \%{ }^{239} \mathrm{Pu}, 25 \%{ }^{240} \mathrm{Pu}$, and $15 \%{ }^{241} \mathrm{Pu}$. The amount of ${ }^{241} \mathrm{Pu}$ is directly related to the amount of ${ }^{241} \mathrm{Am}$ that will be found in the tank. In cores drilled in the Z-12 crib, the $\mathrm{nCi} / \mathrm{g}$ of ${ }^{239} \mathrm{Pu}$ was approximated 4 times the $\mathrm{nCi} / \mathrm{g}$ of ${ }^{241} \mathrm{Am}$ in the mid1970 's. Stated another way, on average the plutonium contains approximately $0.45 \%{ }^{241} \mathrm{Am}$ by weight.

A sample of sludge taken from the settling tank in 1977 had the following isotopic distribution (Bouse 1977a): Isotope, Wt \%, ${ }^{238} \mathrm{Pu} 0.00874 \%,{ }^{239} \mathrm{Pu} 93.7 \%,{ }^{240} \mathrm{Pu} 6.023 \%,{ }^{241} \mathrm{Pu}$ $0.2333 \%,{ }^{241} \mathrm{Am}, 0.4758 \%$. The sample was identified as NW-5 and was selected because it was the core segment with the highest plutonium concentration. Section 5 was at the 60 inch from bottom of tank level in a 90 -inch segment. These values are consistent with the types of material that was processed in PFP. These data indicate that the plutonium in Tank 241-Z-361 has an isotopic distribution consistent with weapons grade plutonium. The americium concentration in $241-\mathrm{Z}-361$ is the same as found in the Z-12 crib. Current isotopic composition (calculated from Bouse 1977 data) is: Isotope $W: \%,{ }^{238} \mathrm{Pu} 0.0074 \%,{ }^{239} \mathrm{Pu} 93.82 \%,{ }^{240} \mathrm{Pu}$ $6.047 \%,{ }^{241} \mathrm{Pu} 0.087 \%,{ }^{241} \mathrm{Am}, 0.61 \%$.

Dressen (1976) and Dodd (1976) reported plutonium concentrations from samples taken in 1975. The numbers reported by Dodd were corrected and reported again to be consistent with the calculation method used by Dressen. The results are shown in Table 7 and Table 8. Examination of raw data in Dodd's notebook (Dodd 1975b) when compared to data later collected by Bouse indicates an error. Dodd filtered the sludge and measured the volume of liquid collected. This volume of liquid collected from filtration, combined with a volume for solids calculated assuming a solid density of $2 \mathrm{~g} / \mathrm{cc}$, was used to report a percent solids in the sludge. When Bouse measured the filtered liquid volume and the additional weight lost by the filtered solids upon drying, it was found that approximately an equal volume of liquid was trapped as was separated by filtration. Another corrected plutonium concentration was calculated and is presented in Table 8 with the results reported by Dodd (1976). See Appendix A for detailed comparison of sampling campaign results. Transcriptions of the notebooks of Dressen and Bouse are presented in Appendices $C$ and $D$.

Table 7. Solids and Plutonium measured in 241-Z-361 Sludge (Dressen).

\begin{tabular}{|r|r|r|r|}
\hline & & \multicolumn{2}{|c|}{ Pu Concentration g/L } \\
\hline Section \# & Vol \% solids & in Solids & in Sludge \\
\hline 2 & 19.2 & 2.18 & 0.42 \\
\hline 4 & 12.8 & 3.37 & 0.43 \\
\hline 6 & 19.5 & 1.89 & 0.37 \\
\hline 8 & 28.4 & 0.89 & 0.25 \\
\hline 10 & 15.8 & 1.97 & 0.31 \\
\hline 12 & 18.7 & 1.11 & 0.21 \\
\hline & avg. & 1.90 & 0.33 \\
\hline & std dev & 0.88 & 0.09 \\
\hline
\end{tabular}


HNF-1989, REV. 1

Table 8. Solids and Plutonium measured in 241-Z-361 Sludge (Dodd).

\begin{tabular}{|c|c|c|c|c|c|c|c|}
\hline $\begin{array}{c}\text { Sample ID } \\
361-Z-\end{array}$ & $\begin{array}{l}\text { Vol ml } \\
\text { Filtrate }\end{array}$ & wt solids & $\begin{array}{c}\text { Corrected } \\
\text { vol\% solids }\end{array}$ & $\begin{array}{l}\text { Pug/L dry } \\
\text { solids }\end{array}$ & $\begin{array}{c}\text { Corrected Pu } \\
\text { in situ } \mathrm{g} / \mathrm{L}\end{array}$ & $\begin{array}{c}\text { PPSL } \\
\text { corrected vol } \\
\% \text { solids }\end{array}$ & \begin{tabular}{|c|} 
PPSL \\
corrected Pu \\
in sludge g/L \\
\end{tabular} \\
\hline $3 "-1-4$ & 62 & 28.7 & 27.2 & 3.1 & 0.84 & 10.4 & $\begin{array}{r}0.32 \\
\end{array}$ \\
\hline $6^{\prime \prime}-1-2$ & 32 & 22.8 & 27.0 & 1.9 & 0.52 & 15.1 & 0.29 \\
\hline $6 "-1-3$ & 46 & 30.5 & 24.8 & & & 14.2 & \\
\hline $6 "-1-5$ & 57 & 27.7 & 19.4 & 1.9 & 0.37 & 10.8 & 0.21 \\
\hline $6^{\prime \prime}-1-6$ & 45 & 25.1 & 21.9 & & & 12.2 & 0.00 \\
\hline $6^{\prime \prime}-1-8$ & 55 & 26.5 & 19.4 & 2.6 & 0.50 & 10.8 & 0.28 \\
\hline $6^{\prime \prime}-1-9$ & 48 & 31.8 & 24.9 & 3.0 & 0.75 & 14.2 & 0.43 \\
\hline $6 "-1-9$ rerun & 48 & 31.8 & 16.4 & 4.1 & 0.67 & 14.2 & 0.58 \\
\hline $6^{\prime \prime}-1-11$ & 50 & 19.6 & 16.4 & 2.6 & 0.43 & 8.9 & 0.23 \\
\hline $6 "-1-13$ & 66 & 15.3 & 10.3 & & & 5.5 & 0.00 \\
\hline $6 "-1-16$ & 37 & 14.8 & $\begin{array}{ll}16.7 \\
\end{array}$ & 2.4 & 0.41 & 9.1 & 0.22 \\
\hline $1-3\left(10^{\prime \prime}\right)$ & 55 & 24.4 & 18.2 & 2.9 & 0.53 & 10.0 & 0.29 \\
\hline $2-2\left(6^{\prime \prime}\right)$ & 128 & 86.0 & 25.1 & 1.5 & 0.38 & 14.4 & 0.22 \\
\hline $2-4\left(10^{\prime \prime}\right)$ & 110 & 62.8 & 22.2 & 2.8 & 0.62 & 12.5 & 0.35 \\
\hline $3-3\left(10^{\prime \prime}\right)$ & 90 & 57.5 & 24.2 & 1.0 & 0.24 & 13.8 & 0.14 \\
\hline $1-2$ & 61 & 20.0 & 14.1 & & & 7.6 & \\
\hline $1-5$ (valve) & 76 & 38.4 & 20.2 & 1.6 & 0.32 & 11.2 & 0.18 \\
\hline $3-2$ & 71 & 47.2 & 24.9 & & & 14.2 & \\
\hline 3-5 (valve) & 84 & 84.3 & 22.4 & 1.4 & 0.31 & 20.1 & 0.28 \\
\hline $2-6$ (valve) & 73 & 48.7 & 25.0 & 2.6 & 0.65 & 14.3 & 0.37 \\
\hline $4-2$ & 85 & 63.9 & 27.4 & 1.6 & 0.43 & 15.8 & 0.25 \\
\hline $4-3$ & 64 & 37.1 & 22.5 & & & 12.7 & \\
\hline 4-5 (valve) & 86 & 85.3 & 33.4 & 0.5 & 0.15 & 19.9 & 0.09 \\
\hline 3-5 (valve) & 36 & 34.3 & 32.3 & 1.8 & 0.58 & 19.2 & 0.35 \\
\hline $4-3$ & 43 & 40.6 & 32.1 & $\overline{0.8}$ & 0.24 & 19.1 & 0.14 \\
\hline $4-5$ (valve) & 45 & 75.3 & 45.5 & 1.2 & 0.56 & 29.5 & 0.37 \\
\hline $4-4$ & 42 & 39.4 & 31.9 & & & 19.0 & \\
\hline $3-1$ & 52 & 16.6 & 13.8 & & & 7.4 & \\
\hline $3-3$ & 43 & 41.0 & 32.3 & 1.1 & 0.37 & 19.2 & 0.22 \\
\hline $3-4$ & 42 & 15.7 & 15.7 & & & 8.6 & 0.00 \\
\hline $4-1$ & 43 & 16.2 & 15.9 & & & 8.6 & 0.00 \\
\hline $3 \mathrm{~B}$ & 48 & 28.5 & 22.8 & 2.7 & 0.62 & 12.9 & 0.3 \\
\hline $3 \mathrm{~B}$ rerun & 48 & 28.5 & 22.8 & 2.4 & 0.54 & 12.9 & 0.31 \\
\hline $5 \mathrm{~B}$ & 48 & 29.0 & 23.2 & 2.9 & 0.67 & 13.1 & 0.3 \\
\hline $7 \mathrm{~B}$ & 56 & 28.0 & 20.0 & 3.0 & 0.61 & 11.1 & 0.34 \\
\hline $7 \mathrm{~B}$ rerun & 56 & 28.0 & 20.0 & 8.6 & \begin{tabular}{|c|}
1.71 \\
\end{tabular} & 11.1 & 0.95 \\
\hline $7 \mathrm{~B}$ rerun & 56 & 28.0 & 20.0 & 10.5 & 2.10 & 11.1 & 1. \\
\hline $13 \mathrm{~B}$ & 72 & 29.8 & 17.1 & 2.8 & 0.47 & 9.4 & 0.26 \\
\hline $15 \mathrm{~B}$ & 64 & 18.4 & 11.1 & 1.9 & 0.21 & 6.7 & 0.12 \\
\hline avg. & & & 22.58 & & 0.58 & 13.10 & 0.29 \\
\hline
\end{tabular}


HNF-1989, REV. 1

An improved method using only the amount of dry solids was used to calculate sludge plutonium concentrations. The method is explained in Appendix $A$ and presented in Table 9. Average values from Bouse data were used when actual data was not available. 
Table 9. Best estimate corrections to Dodd plutonium concentrations 241-Z-361 sludge.

\begin{tabular}{|c|c|c|c|c|}
\hline & Sample ID 361-Z- & wt solids & Pu g/L dry solids & $\begin{array}{l}\text { PPSL corr'd Pu in } \\
\text { sludge - Best } \\
\text { Estimate }\end{array}$ \\
\hline & 3"-1-2 & & 3.0 & 0.39 \\
\hline & $3^{\prime \prime}-1-4$ & 28.7 & 3.1 & 0.40 \\
\hline & $8 "-1-2$ & lost & 2.5 & 0.33 \\
\hline \multirow[t]{12}{*}{ Center Manhole } & $6 "-1-2$ & 22.8 & 1.9 & 0.25 \\
\hline & $6 "-1-3$ & 30.5 & & \\
\hline & $6 "-1-4$ & & & \\
\hline & $6^{\prime \prime}-1-5$ & 27.7 & 1.9 & 0.25 \\
\hline & $6 "-1-6$ & 25.1 & & \\
\hline & $6 "-1-7$ & & & \\
\hline & $6^{\prime \prime}-1-8$ & 26.5 & 2.6 & 0.34 \\
\hline & $6 "-1-9$ & 31.8 & 3.0 & 0.39 \\
\hline & & & 4.1 & 0.54 \\
\hline & $6 "-1-11$ & 19.6 & 2.6 & 0.34 \\
\hline & $6 "-1-13$ & 15.3 & & \\
\hline & $6 "-1-16$ & 14.8 & 2.4 & 0.32 \\
\hline \multirow[t]{12}{*}{ Core Sample 3ftS- } & $1-3\left(10^{\prime \prime}\right)$ & 24.4 & 2.9 & 0.38 \\
\hline & $2-2\left(6^{\prime \prime}\right)$ & 86.0 & 1.5 & 0.20 \\
\hline & $2-4\left(10^{\prime \prime}\right)$ & 62.8 & 2.8 & 0.37 \\
\hline & $3-3\left(10^{\prime \prime}\right)$ & 57.5 & 1.0 & 0.13 \\
\hline & $1-2$ & 20.0 & & \\
\hline & $1-5$ (valve) & 38.4 & 1.6 & 0.21 \\
\hline & $3-2$ & 47.2 & & \\
\hline & 3-5 (valve) & 84.3 & 1.4 & 0.18 \\
\hline & 2-6 (valve) & 48.7 & 2.6 & 0.34 \\
\hline & $4-2$ & 63.9 & 1.6 & 0.21 \\
\hline & $4-3$ & 37.1 & & \\
\hline & $4-5$ (valve) & 85.3 & 0.5 & 0.06 \\
\hline \multirow[t]{8}{*}{$3 \mathrm{ftN}-$} & 3-5 (valve) & 34.3 & 1.8 & 0.23 \\
\hline & $4-3$ & 40.6 & 0.8 & 0.10 \\
\hline & $4-5$ (valve) & 75.3 & 1.2 & 0.16 \\
\hline & $4-4$ & 39.4 & & \\
\hline & & 16.6 & & \\
\hline & $3-3$ & 41.0 & 1.1 & 0.15 \\
\hline & $3-4$ & 15.7 & & \\
\hline & $4-1$ & 16.2 & & \\
\hline
\end{tabular}


Table 9. Best estimate corrections to Dodd plutonium concentrations 241-Z-361 sludge. (cont)

\begin{tabular}{|l|l|l|l|l|}
\hline & Sample ID 361-Z- & wt solids & Pu g/L dry solids & $\begin{array}{l}\text { PPSL corr'd Pu in } \\
\text { sludge - Best } \\
\text { Estimate }\end{array}$ \\
\hline & & & & \\
\hline $\begin{array}{l}\text { 3ft N-15 bottle } \\
\text { sample }\end{array}$ & 1 B & & 0.9 & 0.12 \\
\hline & 2 B & & & \\
\hline & 3 B & 28.5 & 2.7 & 0.35 \\
\hline & & & 2.4 & 0.31 \\
\hline & 4 B & 30.2 & & 0.38 \\
\hline & 5 B & 29.0 & 2.9 & \\
\hline 6 B & & & 0.40 \\
\hline 7 B & 28.0 & 3.0 & 1.37 \\
\hline 8 B & 25.7 & 10.5 & 1.12 \\
\hline & & & 8.6 & 0.39 \\
\hline & & & 3.0 & 0.28 \\
\hline 9 B & & & \\
\hline 10 B & & 2.1 & \\
\hline 11 B & & & \\
\hline 12 B & & & 0.36 \\
\hline 13 B & 29.8 & 2.8 & \\
\hline 14 B & & & \\
\hline 15 B & 18.4 & 1.9 & \\
\hline & & & \\
\hline & & & \\
\hline
\end{tabular}

The last core sample taken was the one that was analyzed and documented most thoroughly. The results are presented in Table 10. 
Table 10. Sludge analysis results from 1977 North West sampling (Bouse).

\begin{tabular}{|l|r|r|r|r|r|r|}
\hline & $\begin{array}{c}\text { Dried Solids } \\
\text { Density } \\
\text { (g/L) }\end{array}$ & $\begin{array}{c}\text { Pu Solids } \\
\text { (g/L) }\end{array}$ & $\begin{array}{c}\text { Volume \% } \\
\text { Solids in } \\
\text { Sample }\end{array}$ & $\begin{array}{c}\text { Pu in } \\
\text { Sludge (g/L) } \\
\text { based on } \\
\text { dried }\end{array}$ & $\begin{array}{c}\text { Pu g/L } \\
\text { sludge } \\
\text { (NDA) }\end{array}$ & $\begin{array}{c}\text { Wet } \\
\text { analysis/ } \\
\text { NDA }\end{array}$ \\
\hline NW-1 & 2.08 & 1.02 & $9 \%$ & 0.09 & 0.27 & 0.32 \\
\hline NW-2 & 1.86 & 0.84 & $11 \%$ & 0.10 & 0.29 & 0.33 \\
\hline NW-3 & 2.17 & 0.86 & $13 \%$ & 0.12 & 0.35 & 0.33 \\
\hline NW-4 & 2.50 & 1.00 & $13 \%$ & 0.13 & 0.25 & 0.54 \\
\hline NW-5 & 1.69 & 0.87 & $36 \%$ & 0.32 & 0.60 & 0.52 \\
\hline NW-6 & 1.63 & 1.20 & $27 \%$ & 0.32 & 0.23 & 1.44 \\
\hline NW-7 & 1.79 & 1.15 & $15 \%$ & 0.18 & 0.59 & 0.30 \\
\hline NW-8 & 2.17 & 1.27 & $11 \%$ & 0.14 & 0.18 & 0.77 \\
\hline NW-9 & 1.56 & 0.62 & $35 \%$ & 0.22 & 0.37 & 0.59 \\
\hline NW-10 & 1.50 & 0.74 & $32 \%$ & 0.24 & 0.28 & 0.84 \\
\hline NW-11 & 1.56 & 0.41 & $31 \%$ & 0.13 & 0.20 & 0.63 \\
\hline NW-12 & 1.71 & 0.54 & $31 \%$ & 0.17 & 0.17 & 0.99 \\
\hline
\end{tabular}

The sludge contained layers of different material. These are described for the 1977 sludge samples in Table 11. This layering indicates that solids settled from waste and did not mix with existing sludge.

Table 11. Sample descriptions for 1977 Sludge sample.

\begin{tabular}{|l|l|}
\hline & \multicolumn{1}{|c|}{ Sample Description } \\
\hline NW-1 & Dark Brown -almost Black - loose -wet \\
\hline NW-2 & Color of Sample 1 - thicker \\
\hline NW-3 & Smali amount of free liquid on top Color of sample 1 - thicker than 2 \\
\hline NW-4 & Dark brown -lighter than 2- thinner \\
\hline NW-5 & Lighter color than 4 - very watery - thin soup \\
\hline NW-6 & Thicker than 5 - lighter color than 5 - gritty - sandy \\
\hline NW-7 & Thicker than 6 - dark tank color - pasty, creamy consistency \\
\hline NW-8 & same a 7 except lighter color \\
\hline NW-9 & $\begin{array}{l}\text { Free liquid on top - only slightiy darker color than 8 - same } \\
\text { consistency }\end{array}$ \\
\hline NW-10 & same as 9 \\
\hline NW-11 & tan-brown Same at 10 - slightly a darker \\
\hline NW-12 & Lot of liquid on top. Lt. brown darker than 5 above samples \\
\hline
\end{tabular}




\section{CRIBS}

When the settling tank was filled to the overflow level, the liquid flowed by gravity to one of the cribs. Composition of the material in the settling tank can be inferred from descriptions of material being sent to the cribs. Routing to Z-1A appears to have changed between 1959 and 1964. Up until 1959, the overflow from $Z-1,2$, and 3 went to $Z-1 A$. When those cribs were taken out of service, Z-1A was not used for 5 years. When Z-1A was extended and put back in service in 1964, it is believed there was a waste route that did not include the 241-Z-361 settling tank.

Plutonium discharged to cribs that used $241-Z-361$ for settling solids is plotted in Figure 3. From June 1949 to July 1952 the cribs used were $Z-1$ and $Z-2$ and there was $199 \mathrm{~g}$ plutonium discharged. July 1952 through March 1959 Crib Z-3 received waste from 241-Z-361. In March 1959 , Crib Z-12 replaced Z-3. Waste was discharge to Z-12 until the same time as $241-Z-361$ was taken out of service in May 1973. The analyses of sludge plutonium concentrations compared to the amount of plutonium discharged to the cribs indicate that most of the plutonium remained in the settling tank. Considering that plutonium is insoluble at the $\mathrm{pH}$ of solution discharged to the cribs, this is what would be expected. Data used to produce Figure 3 are listed in Appendix D. As can be seen in the figure, the discharge of plutonium is spread fairly consistently over the life of the tank. 
Table 12. Cribs receiving waste from $241-Z$ (Knight).

\begin{tabular}{|l|l|l|l|l|}
\hline Number & Description & $\begin{array}{l}\text { Use } \\
\text { From }\end{array}$ & $\begin{array}{l}\text { Use } \\
\text { To }\end{array}$ & Status \\
\hline $216-Z-1$ & $\begin{array}{l}\text { 231-Z, 234-5 } \\
\text { Cooling Water } \\
\text { Ditch }\end{array}$ & $12 / 44$ & $3 / 59$ & $\begin{array}{l}\text { Terminated - } \\
\text { Backfilled }\end{array}$ \\
\hline 216-Z-1 & D-6 Waste & $6 / 49$ & $4 / 69$ & Terminated \\
\hline & U & $3 / 68$ & $5 / 68$ & \\
\hline $216-Z-1 A$ & $\begin{array}{l}\text { Overflow from Z- } \\
1,2 \text { and 3 }\end{array}$ & $6 / 49$ & $3 / 59$ & $\begin{array}{l}\text { Replaced by } \\
\text { Z-12 }\end{array}$ \\
\hline & $\begin{array}{l}\text { Reclamation } \\
\text { Waste }\end{array}$ & $6 / 64$ & $3 / 69$ & $\begin{array}{l}\text { Replaced by } \\
\text { Z-18 }\end{array}$ \\
\hline $216-Z-2$ & $\begin{array}{l}\text { D-6 Waste } \\
\text { Reclamation } \\
\text { Waste }\end{array}$ & $4 / 49$ & $6 / 52$ & $\begin{array}{l}\text { Replaced by } \\
\text { Z-3 }\end{array}$ \\
\hline CAW & $5 / 66$ & $6 / 66$ & $\begin{array}{l}\text { Temporary } \\
\text { routing }\end{array}$ \\
\hline $216-Z-12$ & D-6 Waste & $6 / 52$ & $5 / 73$ & Inactive \\
\hline
\end{tabular}


HNF-1989, REV. 1

Figure 3. Cumulative Plutonium Discharged to Cribs Serviced by $241-Z-361$.

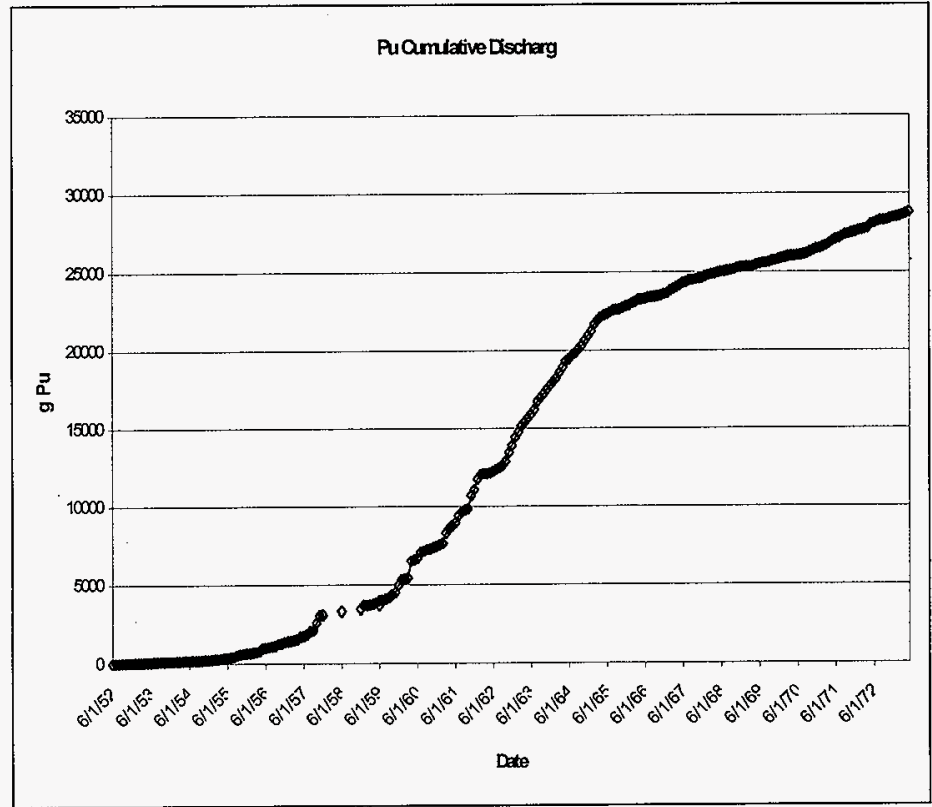




\section{CONCLUSIONS}

Despite the large number of unanswered questions about the chemicals in the sludge several observations can be made.

Core samples of sludge taken in 1975 through 1977 all indicated layering in the sludge. For there to be distinct layers indicates there was no mixing of the sludge after solids settle. From this it can be inferred that migration of plutonium to form pockets of higher concentration would not occur.

Much of the plutonium in the sludge came from the incinerator scrubber. The plutonium would likely be present as plutonium oxide. When the fluorinator was operating, the plutonium may have been plutonium fluoride. Neutralization of PRF low-salt waste would have resulted in hydrous oxides of plutonium coprecipitating with large volumes of hydrous oxides of other metals.

Dodd indicated the sludge samples were difficult to dissolve even in B-acid (12 M HNO3, $0.5 \mathrm{M} \mathrm{HF}$ ). Large volumes of water were discharged through this tank. Soluble components would have been washed away at that time. Addition of water to the tank would not dissolve the plutonium or other solids.

One question being asked is "What's the current $\mathrm{pH}$ ?" The information is not available as to what the $\mathrm{pH}$ of the sludge or streams into the tank were. It seems that the statements that the waste was neutralized to $\mathrm{pH} 10$ or 12 are erroneous. Some of it may have been, but it appears that not all of it was. Unfortunately, the $\mathrm{pH}$ was not measured and recorded in the sampling campaigns.

The $\mathrm{pH}$ is sufficiently high (greater than 2) that plutonium is not mostly insoluble.

PRF low salt waste contained CCl4, TBP, DBP, MBP, and butanol. Transfer of this waste to the settling tank was accomplished using steam jetting. The $\mathrm{CCl} 4$ was likely steam distilled from the waste stream. The butyl phosphates and alcohol likely stayed in solution and were transferred to the cribs. Some may remain in the waste. Conditions that are required to form reactive degradation products do not exist in this tank. Reactive mixtures of tributyl phosphate require concentrated nitric acid and elevated temperatures to form.

The tank carbon steel liner has been dissolved through corrosion. This was evident from photographs in 1975.

Some degradation of the concrete tank has occurred, but is most of the concrete remains intact.

There is no separate organic phase in the tank. Organic compounds in the waste possibly include carbon tetrachloride ( $\mathrm{CCl} 4$ ), tributyl phosphate (TBP), lard oil (triolein), and various complexants and solvents from the laboratories. The volatile compounds such as $\mathrm{CCl} 4$ may have been steam-distilled from the waste during the steam jetting transfer from the $241-\mathrm{Z}$ sump tanks to the cribs. Folklore has it that steam rose from the settling tank during the transfers. Nonvolatile organic compounds constituted a very small portion of a large volume of waste. 
These would likely be distributed through the waste. A separate organic phase is not expected.

The plutonium in the tank has not migrated or segregated

Layers that were observed in samples of the sludge will still be stratified. There is no mechanism for mixing in the tank. The solids settled over many years and are expected to remain in the layered configuration.

Some drying of the sludge has occurred, but the volume of the sludge has not decreased significantly. The tank was blanked off in 1973. Supernate liquid was pumped from the tank and the tank was sealed. There is no active ventilation. The tank is expected to breathe through loose-fitting covers. The contents are not generating much heat, so the sludge is not expected to be dry.

The tanks sludge may contain some or all of the components listed in Table 13. This list is based on the processes that were known or suspected to send waste to 241-Z-361 and analyses of the nonradioactive components in the tank. 
HNF-1989, REV. 1

Table 13. Known and Probable Components of 241-Z-361 Tank Sludge.

\begin{tabular}{|c|c|c|}
\hline Type of Component & Component & Probable Source \\
\hline \multirow[t]{5}{*}{ Known Metals } & $\mathrm{Al}$ & Waste Treatment \\
\hline & $\mathrm{Na}$ & Incinerator Off-gas Treatment \\
\hline & $\mathrm{Ca}$ & Waste Treatment \\
\hline & $\mathrm{Si}$ & Incinerator Off-gas Treatment \\
\hline & $\mathrm{Cd}$ & Most likely Analytical Artifact \\
\hline \multirow[t]{5}{*}{ Known Non-Metals } & $\mathrm{F}^{-}$ & Hydrogen Fluorinator \\
\hline & $\mathrm{Cl}^{-}$ & Waste Treatment \\
\hline & $\begin{array}{l}\text { C (organic or } \\
\text { total?) }\end{array}$ & Incinerator Off-gas Treatment \\
\hline & $\mathrm{H}_{2} \mathrm{O}$ & All \\
\hline & $\mathrm{H}^{+}$ & All \\
\hline \multirow[t]{6}{*}{ Probable Metals } & $\mathrm{Pb}$ & Incinerator Off-gas Treatment \\
\hline & $\mathrm{Mg}$ & Waste Treatment \\
\hline & $\mathrm{Mn}$ & Waste Treatment \\
\hline & $\mathrm{Cr}$ & Corrosion of SS Equipment \\
\hline & $\mathrm{Ni}$ & Corrosion of SS Equipment \\
\hline & $\mathrm{Ag}$ & Lab Film Processing \\
\hline \multirow[t]{5}{*}{$\begin{array}{l}\text { Probable Non- } \\
\text { Metals }\end{array}$} & $\mathrm{NO}_{3}^{-}$ & Waste Treatment \\
\hline & $\mathrm{NO}_{2}^{-}$ & Radiolysis of $\mathrm{NO}_{3}^{-}$ \\
\hline & $\mathrm{SO}_{4}^{2-}$ & Waste Treatment \\
\hline & $\mathrm{PO}_{4}^{3-}$ & Degradation of TBP \\
\hline & $\mathrm{CO}_{3}{ }^{2-}$ & Incinerator Off-gas Treatment \\
\hline \multirow[t]{12}{*}{ Probable Organics } & $\mathrm{CCl}_{4}$ & Waste Treatment \\
\hline & DBBP & Waste Treatment \\
\hline & TBP & Waste Treatment \\
\hline & DBP & Degradation of TBP \\
\hline & MBP & Degradation of TBP \\
\hline & Butanol & Degradation of TBP \\
\hline & Urea & Incinerator Off-gas Treatment \\
\hline & Lard Oil (Triolein) & Waste Treatment \\
\hline & Oxalic Acid & Waste Treatment \\
\hline & Acetic Acid & Incinerator Off-gas Treatment \\
\hline & Benzene & Incinerator Off-gas Treatment \\
\hline & Phthalic Acid & Incinerator Off-gas Treatment \\
\hline \multirow{3}{*}{$\begin{array}{l}\text { Known } \\
\text { Radionuclides }\end{array}$} & $\mathrm{Pu}$ & All \\
\hline & $\mathrm{Am}$ & Decay of $\mathrm{Pu}^{241}$ \\
\hline & $\mathrm{U}$ & Waste Treatment \\
\hline
\end{tabular}




\section{REFERENCES}

Barrington, C. A., 1990, Internal Memo to L. H Rodgers, Waste Characterization of Plutonium Finishing Plant Waste to 241-Z, 12362-90-LHR-072, Westinghouse Hanford Co., Richland, Washington.

Bouse, D. G., 1977a, Laboratory Notes: Z Plant Process Assistance, Controlled Notebook ARH-N-375, Atlantic Richfield Hanford Company, Richland, WA.

Bouse, D. G., 1977b, Memo to M. R. Fox, Engineering Assistance - Tank 361-Z Characterization. This is attachment 9 to Internal Letter No. 15530-97-HRR-036

Bouse, D. G., 1977c, Memo to M. R. Fox, Engineering Assistance - Tank 361-Z Characterization. This is attachment 9 to Internal Letter No. 15530-97-HRR-036.

Crawley, D. T., 1975, 361-Z History, Letter to D. G. Harlow, Atlantic Richfield Hanford Co., Richland, Washington, October 30, 1975.

Dodd, D. A., 1975a, Letter to D. C. Lini, Engineering Assistance - Pu Recovery, Atlantic Richfield Hanford Company, Richland, Washington, December 1975.

Dodd, D. A., 1975b, Laboratory Notes: Plutonium Processing, Controlled Notebook ARH-N-342, Aflantic Richfield Hanford Company, Richland, WA.

Dodd, D. A., 1976, Letter to D. C. Lini, Results of 361-Z Sludge Characterization, Atlantic Richfield Hanford Company, Richland, Washington, November 22, 1976.

Dodd, D. A., and W. H. Price, 1976, 241-Z-361 Tank Sludge, Letter to D. C. Bartholomew, Atlantic Richfield Hanford Company, Richland, Washington

Dressen, A. L., 1976, 361-Z Sludge Characterization, Letter to D. T. Crawley, Atlantic Richfield Hanford Company, Richland, Washington

Kasper, R. B., 1980, 216-Z-12 Crib Status Report, March 1980, Rockwell Hanford Co., Richland, Washington.

Kasper, R. B., 1982, 216-Z-12 Transuranic Crib Characterization Operational History and Distribution of Plutonium and Americium, RHO-ST-44, Rockwell Hanford Operations, Richland, Washington.

Knight, L. M., P. L. Merrick, and G. W. Upington, 1968, Waste Management Program Plutonium Finishing Facility, ARH-1740, Atlantic Richfield Hanford Company, Richland, Washington.

Lundgren, Larry, 1975, 361-Z Settling Tank Analysis, Letter to Ken Gaylord, March 18, 1975.

Rhodes, D. W., 1957, Adsorption of Plutonium by Soil, Soil Science, 84, p. 465. 
Rodgers, L. H., 1991, Internal Memo to E. C. Vogt, Assessment of D-4 Drains for Inadvertent Transfers, 15520-91-LHR-022, Westinghouse Hanford Co., Richland, Washington.

Wagoner, John D., 1997, Contract No. DE-AC06-96RL13200 - Unreviewed Safety Question (USQ) Regarding Plutonium Finishing Plant (PFP) Tank 241-Z-361, DOE-RL Letter 97-TPD-193, October 15, 1997 
HNF-1989, REV. 1

APPENDIX: A

DETAILED EXPLANATION OF CALCULATIONS APPLIED TO PLUTONIUM CONCENTRATION MEASUREMENT IN TANK 241-Z-361 SLUDGE 
HNF-1989, REV. 1

November 1976, D. A. Dodd (Dodd 1976) wrote a letter correcting data that was reported December 1975 (Dodd 1975). This section provides an explanation of the corrections made and an evaluation of the measurement methods used for samples of 241-Z-361 sludge analyzed by Dodd, Bouse and Dressen.

\section{EXAMINATION OF DODD DATA}

\begin{tabular}{|c|c|c|c|c|c|c|c|c|c|c|}
\hline 1 & 2 & 3 & 4 & 5 & 6 & 7 & 8 & 9 & 10 & 11 \\
\hline & $\begin{array}{l}\text { Sample ID } \\
361-Z-\end{array}$ & $\begin{array}{l}\text { Vol ml } \\
\text { Filtrate }\end{array}$ & wt filtrate & wt solids & $\begin{array}{l}\text { Vol (calc) } \\
\text { solids }\end{array}$ & $\begin{array}{l}\text { vol \% } \\
\text { solids }\end{array}$ & $\begin{array}{l}\text { Corrected } \\
\text { vol } \% \\
\text { solids }\end{array}$ & $\begin{array}{l}\text { Pu g/L dry } \\
\text { solids }\end{array}$ & $\begin{array}{l}\text { Pu in } \\
\text { sludge }\end{array}$ & $\begin{array}{l}\text { Corrected } \\
\mathrm{Pu} \text { in situ }\end{array}$ \\
\hline & $3 "-1-2$ & & & & & & & 3.0 & & \\
\hline & $3^{\prime \prime}-1-4$ & 62 & & 28.7 & 23.2 & 37.4 & 27.2 & 3.1 & 1.16 & 0.84 \\
\hline & $8^{\prime \prime}-1-2$ & lost & & lost & & & & 2.5 & & \\
\hline Center & $6^{\prime \prime}-1-2$ & 32 & & \begin{tabular}{|r|}
22.8 \\
\end{tabular} & 11.8 & 35.6 & 27.0 & 1.9 & 0.69 & 0.52 \\
\hline \multirow[t]{12}{*}{ Manhole } & $6^{\prime \prime}-1-3$ & 46. & 46.1 & 30.5 & 15.2 & & 24.8 & & & \\
\hline & $6^{\prime \prime}-1-4$ & & & & & & & & & \\
\hline & $6^{\prime \prime}-1-5$ & 57 & 56.9 & 27.7 & 13.8 & 24.7 & 19.4 & 1.9 & 0.47 & 0.37 \\
\hline & $6^{\prime \prime}-1-6$ & 45 & 44.8 & 25.1 & 12.6 & 27.9 & 21.9 & & & \\
\hline & $6^{\prime \prime}-1-7$ & & & & & & & & & \\
\hline & $6 "-1-8$ & 55 & 56.2 & 26.5 & 13.2 & 24.0 & 19.4 & 2.6 & 0.62 & 0.50 \\
\hline & $6 "-1-9$ & 48 & 47.9 & 31.8 & 15.9 & 33.1 & 24.9 & 3.0 & 0.99 & 0.75 \\
\hline & & & & & & & 16.4 & 4.1 & 0.00 & 0.67 \\
\hline & $6^{\prime \prime}-1-11$ & 50 & 50.4 & 19.6 & 9.8 & 19.6 & 16.4 & 2.6 & 0.51 & 0.43 \\
\hline & $6^{\prime \prime}-1-13$ & 66 & 66.3 & 15.3 & 7.6 & & 10.3 & & 0.00 & \\
\hline & $6^{\prime \prime}-1-16$ & 37 & & 14.8 & 7.4 & 20.0 & 16.7 & 2.4 & 0.49 & 0.41 \\
\hline & & & & & & & & & 0.00 & \\
\hline Core & $1-3\left(10^{\prime \prime}\right)$ & 55 & & 24.4 & 12.2 & 22.2 & 18.2 & 2.9 & 0.64 & 0.53 \\
\hline Sample & $2-2\left(6^{\prime \prime}\right)$ & 128 & & 86.0 & 43.0 & 39.5 & 25.1 & 1.5 & 0.59 & 0.38 \\
\hline \multirow{10}{*}{ 3ftS- } & $2-4\left(10^{\prime \prime}\right)$ & 110 & & 62.8 & 31.4 & 33.5 & 22.2 & 2.8 & 0.94 & 0.62 \\
\hline & $3-3\left(10^{\prime \prime}\right)$ & 90 & & 57.5 & 28.8 & 37.6 & 24.2 & 1.0 & 0.38 & 0.24 \\
\hline & $1-2$ & 61 & & 20.0 & 10.0 & & 14.1 & & 0.00 & \\
\hline & $1-5$ (valve) & 76 & & 38.4 & 19.2 & 25.3 & 20.2 & 1.6 & 0.40 & 0.32 \\
\hline & $3-2$ & 71 & & 47.2 & 23.6 & & 24.9 & & 0.00 & \\
\hline & 3-5 (valve) & 84 & & 84.3 & 42.2 & 50.1 & 33.4 & 1.4 & 0.70 & 0.47 \\
\hline & 2-6 (valve) & 73 & & 48.7 & 24.3 & 33.3 & 25.0 & 2.6 & 0.87 & 0.65 \\
\hline & $4-2$ & 85 & & 63.9 & 32.0 & 37.5 & 27.3 & 1.6 & 0.59 & 0.43 \\
\hline & $4-3$ & 64 & & 37.1 & 18.6 & & 22.5 & & 0.00 & \\
\hline & $4-5$ (valve) & 86 & & 85.3 & 42.6 & 49.5 & 33.2 & 0.5 & 0.22 & 0.15 \\
\hline \multirow[t]{8}{*}{$3 \mathrm{ft} \mathrm{N-}$} & 3-5 (valve) & 36 & & 34.3 & 17.2 & 47.8 & 32.3 & 1.8 & 0.86 & 0.58 \\
\hline & $4-3$ & 43 & & 40.6 & 20.3 & 47.2 & 32.1 & 0.8 & 0.35 & 0.24 \\
\hline & 4-5 (valve) & 45 & & 75.3 & 37.6 & 83.6 & 45.5 & 1.2 & 1.04 & 0.56 \\
\hline & $4-4$ & 42 & & 39.4 & 19.7 & 46.9 & 31.9 & $\cdot$. & & \\
\hline & & 52 & & 16.6 & 8.3 & 16.0 & 13.8 & & & \\
\hline & $3-3$ & 43 & & 41.0 & 20.5 & 47.7 & 32.3 & 1.1 & 0.54 & 0.37 \\
\hline & $3-4$ & 42 & & 15.7 & 7.8 & 18.7 & 15.7 & & & \\
\hline & $4-1$ & 43 & & 16.2 & 8.1 & 18.8 & 15.9 & & & \\
\hline $3 \mathrm{ft} \mathrm{N}-15$ & $1 \mathrm{~B}$ & & & & & 60.5 & & 0.9 & 0.55 & \\
\hline Bottle & $3 \mathrm{~B}$ & 48 & & 28.5 & 14.2 & 29.7 & 22.8 & 2.7 & 0.80 & 0.62 \\
\hline sample & & & & & & & & 2.4 & & \\
\hline & $4 \mathrm{~B}$ & 53 & & 30.2 & 15.1 & 28.5 & 22.2 & & & \\
\hline
\end{tabular}


HNF-1989, REV. 1

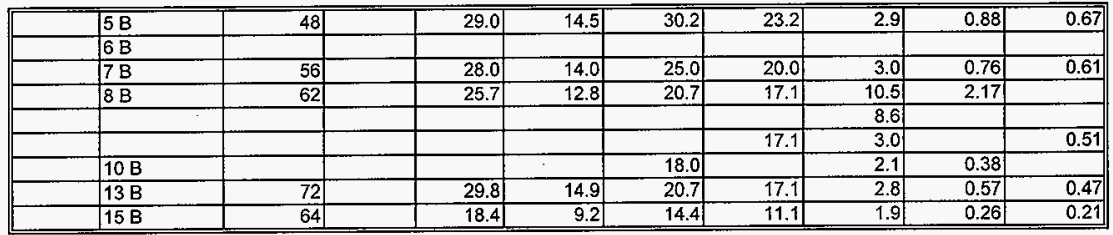

Column 1:

Sampling location.

Column 2:

Sample ID

Column 3:

Volume in $\mathrm{mL}$ of filtrate collected from vacuum filtration of the sludge.

Column 4:

Weight of the filtrate collected.

The density of the sludge was calculated using the values in columns 3 and 4 as follows

Column 5:

$$
\rho_{\text {fitrate }}=\frac{\text { Weight }_{\text {fitrate }}}{\text { Volume }_{\text {fitrate }}}
$$

Weight of solids. This is the weight of solids that remained after filtering and air-drying.

Column 6:

Volume (calculated) solids. With the exception of samples 3-1-4 and 6-1-2, this value is the weight of solids (column 5) divided by 2 . This value of 2 appears to be an assumed density of the solids in $\mathrm{g} / \mathrm{mL}$ or $\mathrm{g} / \mathrm{cm}^{3}$.

$$
V o l_{\text {calc }}=\frac{\text { Weight }}{\rho_{\text {solids }}}
$$

Column 7:

Volume percent solids was then calculated as the volume of solids (column 6 ) divided by the volume of filtrate (column 3 ) divided by 2 and times 100 (to convert to percentage). It is not clear what reason was used for the division by 2 . Restated, the equation used to calculate volume percent solids was

$$
V o l \% \text { solids }=\frac{v o l_{\text {calc,solids }}}{v o l_{\text {sitrate }} / 2} * 100=\frac{W^{2} i g h t_{\text {solids }}}{v o l_{\text {fitrute }}} * 100
$$


HNF-1989, REV. 1

Column 8:

These are the values of the "corrected" volume percent solids. In the 1976 letter reporting these results, Dodd states that since the time when the results were first reported, "additional samples had been analyzed by A. L. Dressen. The percent solids were not calculated on the same basis." The "corrected" values were calculated using the equation

$$
\text { Vol } \% \text { solids }=\frac{\text { Weight }_{\text {solids }} / 2}{\left(2 * v_{\text {ollurate }}\right)+\text { Weight }_{\text {solids }} / 2} * 100
$$

Restating this equation in terms of the columns of data

$$
\text { Vol\%solids }=\frac{\text { Column } 6}{(2 * \text { Column } 3)+\text { Column } 6} * 100
$$

Column 9:

These numbers are assumed to be values calculated from laboratory plutonium concentration measurements from dissolution of a weighed amount of dry solids.

Column 10:

Plutonium in sludge was calculated from the corrected volume percent solids (column 8) multiplied by the concentration of plutonium in dry solids (column 9) divided by 100.

$$
P u_{\text {sludge }}(g / L)=P u_{\text {solids }}(g / L) * \text { vol\% } \% \text { solids } \text { corr } * 100
$$

\section{EXAMINATION OF DRESSEN DATA}

Data collected by Dressen is summarized below.

\begin{tabular}{|l|r|l|r|r|r||}
\hline $\begin{array}{l}\text { SAMPLE } \\
\text { NUMBER }\end{array}$ & WT. SLUDGE & $\begin{array}{l}\text { DENSITY } \\
\text { SLUDGE }\end{array}$ & WT. SOLIDS & $\begin{array}{l}\text { DENSITY } \\
\text { SOLIDS }\end{array}$ & $\begin{array}{l}\text { VOL } \% \\
\text { SOLIDS }\end{array}$ \\
\hline NE-2 & 225.8 & 1.4 & 77.5 & 2.5 & $19.2 \%$ \\
\hline NE-4 & 251.6 & 1.6 & 60.6 & 3 & $12.8 \%$ \\
\hline NE-6 & 258.4 & 1.6 & 70.8 & 2.25 & $19.5 \%$ \\
\hline NE-8 & 249 & 1.4 & 101.2 & 2 & $28.4 \%$ \\
\hline NE-10 & 400.9 & 1.6 & 99.3 & 2.5 & $15.9 \%$ \\
\hline NE-12 & 100 & 1.5 & 31.1 & 2.5 & $18.7 \%$ \\
\hline NE-3 & 263.9 & 1.5 & 134 & 1.67 & $45.6 \%$ \\
\hline NE-5 & 444.2 & 1.05 & 184.5 & 2 & $21.8 \%$ \\
\hline
\end{tabular}

The weight of sludge was the weight of the sludge as received. Density of the sludge was measured either by placing sludge in a graduated cylinder and measuring the weight and volume (for the flowable sludge) or by adding about a gram of sample to a graduated 
cylinder containing about $5 \mathrm{~mL}$ of NPH and recording the volume change (for sludge that was "largely solids"). The sludge was filtered and air-dried over night. Dried solids were weighed. Density of dried solids was determine by placing a weighed amount of solids into a know volume of NPH and determining the solid volume. Volume percent solids was calculated using the equation

$$
\text { vol\%solids }=\frac{W \text { eight }_{\text {solids }} * \rho_{\text {sludge }}}{W e i g h t_{\text {sludge }} * \rho_{\text {solids }}} * 100
$$

The concentration of plutonium in sludge was calculated by multiplying the concentration of plutonium in dried solids by the volume percent solids in sludge.

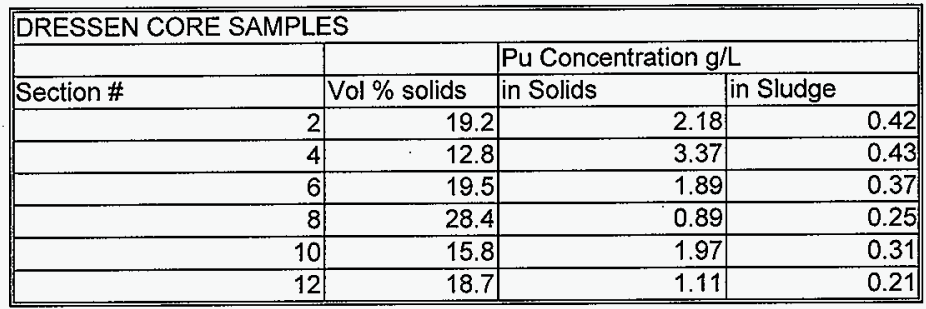

\section{EVALUATION OF BOUSE DATA (ARH-N-375)}

Bouse measured the density of sludge by placing a sample in a graduated cylinder and measuring the volume but said that measure produced "unbelievably low" specific gravities. The method used was to place approximated 20 grams of sample in a tared centrifuge cone, centrifuge the sludge for 10 minutes, and then read the meniscus of the clear liquid on top of the sludge for a total sludge volume. The specific gravity was calculated by dividing the weight of sludge by the volume observed following centrifuging.

The container of sludge was weighed, sludge was transferred to a filter, and the weight of the empty container was weighed. This was done because quantitative transfer of the sludge was not possible. After filtering, the sludge was air-dried. The volume of filtrate collected was also measured. Bouse found that the weight of filtrate plus the weight of dried solids left much weight not accounted for. He concluded that weight must be due to the liquid trapped in the filter cake that is lost when the sludge is air-dried.

Density of the solids was measured by adding approximately $1 \mathrm{gram}$ of solids to a graduated cylinder containing $5 \mathrm{~mL}$ of NPH and the final volume recorded. Volume percent solids was calculated using the method of Dressen.

\begin{tabular}{||l|c|c|c|c|c|c|c|c|c|}
\hline \hline & 1 & 2 & 3 & 4 & 5 & 6 & 7 & 8 & 9 \\
\hline NW-1 & 38.88 & 198.17 & 18.69 & 197.58 & $7.11 \mathrm{E}-03$ & 19.13 & $1.91 \mathrm{E}+01$ & 1.02 & 0.089 \\
\hline NW-2 & 64.16 & 266.55 & 34.49 & 265.22 & $1.25 \mathrm{E}-02$ & 29.06 & $2.91 \mathrm{E}+01$ & 0.84 & 0.095 \\
\hline
\end{tabular}


HNF-1989, REV. 1

\begin{tabular}{|l|r|r|r|r|r|r|r|r|r||}
\hline NW-3 & 87.57 & 239.17 & 40.35 & 239.17 & $9.09 \mathrm{E}-03$ & 34.68 & $3.47 \mathrm{E}+01$ & 0.86 & 0.116 \\
\hline NW-4 & 84.43 & 207.72 & 33.77 & 207.51 & $8.09 \mathrm{E}-03$ & 33.77 & $3.38 \mathrm{E}+01$ & 1.00 & 0.135 \\
\hline NW-5 & 140.59 & 146.92 & 83.19 & 146.19 & $7.20 \mathrm{E}-03$ & 72.40 & $7.24 \mathrm{E}+01$ & 0.87 & 0.315 \\
\hline NW-6 & 110.24 & 177.60 & 67.63 & 176.37 & $2.29 \mathrm{E}-03$ & 80.81 & $8.08 \mathrm{E}+01$ & 1.20 & 0.319 \\
\hline NW-7 & 52.14 & 163.30 & 29.13 & 162.16 & $5.19 \mathrm{E}-03$ & 33.55 & $3.36 \mathrm{E}+01$ & 1.15 & 0.171 \\
\hline NW-8 & 61.61 & 214.68 & 28.39 & 213.19 & $9.17 \mathrm{E}-03$ & 36.04 & $3.60 \mathrm{E}+01$ & 1.27 & 0.138 \\
\hline NW-9 & 151.69 & 177.35 & 97.24 & 176.12 & $3.87 \mathrm{E}-03$ & 60.68 & $6.07 \mathrm{E}+01$ & 0.62 & 0.221 \\
\hline NW-10 & 130.32 & 170.65 & 86.88 & 168.96 & $3.89 \mathrm{E}-03$ & 64.38 & $6.44 \mathrm{E}+01$ & 0.74 & 0.238 \\
\hline NW-11 & 80.89 & 106.36 & 51.85 & 105.52 & $2.00 \mathrm{E}-03$ & 21.35 & $2.14 \mathrm{E}+01$ & 0.41 & 0.128 \\
\hline NW-12 & 152.64 & 190.38 & 89.26 & 188.87 & $3.97 \mathrm{E}-03$ & 48.08 & $4.81 \mathrm{E}+01$ & 0.54 & 0.167 \\
\hline
\end{tabular}

\begin{tabular}{|l|l|}
\hline COLUMN \# & COMMENT \\
\hline $1-$ & Total solids in sample gm. Initial sample wt $\times$ w/o dried solids \\
\hline $2-$ & Total liquid gm - solids wt minus told sample wt \\
\hline $3-$ & Total solids volume $-\mathrm{ml}$ Total solids wt/spGr \\
\hline $4-$ & total volume liquid $-\mathrm{mL}$. Total liquid $\mathrm{wt} / \mathrm{spGr}$ \\
\hline $5-$ & Total Pu in liquid $-\mathrm{mg}$ \\
\hline $6-$ & Total Pu in sludge $-\mathrm{mg}$ \\
\hline $7-$ & Total Pu in Sludge $-\mathrm{gm}-\mathrm{Pu}$ in liquid $+\mathrm{Pu}$ in solids \\
\hline $8-$ & Pu in solids g/L \\
\hline $9-$ & Pu in Sludge $\mathrm{g} / \mathrm{L}$ \\
\hline
\end{tabular}

\section{CONCLUSIONS}

Dodd's calculations use assumed densities for sludge and solids and approximated the amount of liquid in the siudge. These values are used to calculate the concentration of plutonium in sludge. Based on the data collected by both Dressen and Bouse, there is considerable variation in the actual samples. A comparison is listed below.

A recalculation of Dodd's data was performed using the following assumptions:

- Dodd used a solids density of $2 \mathrm{~g} / \mathrm{cm}^{3}$ to calculate concentration of solids in the dry solids.

- Dodd used a sludge density of $1 \mathrm{~g} / \mathrm{cm}^{3}$.

- The average sludge density from Bouse was $1.15 \mathrm{~g} / \mathrm{cm}^{3}$.

- The average dried solids weight fraction of total sample (from Bouse) was $22.7 \%$

The best value that can be calculated from the available data eliminates the volume percent solids value from the calculation. The corrected concentration is then calculated using

$$
P u_{\text {insitu }}=\frac{P u_{\text {solids }} * 1.15 \mathrm{~g} / \mathrm{cm}^{3}}{.227}
$$




\begin{tabular}{|c|c|c|c|c|}
\hline & $\begin{array}{l}\text { SAMPLE ID } \\
361-Z-\end{array}$ & $\begin{array}{l}\text { WT } \\
\text { SOLIDS }\end{array}$ & $\begin{array}{l}\text { PU G/L DRY } \\
\text { SOLIDS }\end{array}$ & $\begin{array}{l}\text { PPSL CORR'D } \\
\text { PU IN SLUDGE } \\
\text { - BEST } \\
\text { ESTIMATE }\end{array}$ \\
\hline & $3 "-1-2$ & & 3.0 & 0.39 \\
\hline & $3 "-1-4$ & 28.7 & 3.1 & 0.40 \\
\hline & $8 "-1-2$ & lost & 2.5 & 0.33 \\
\hline \multirow[t]{12}{*}{ Center Manhole } & $6 "-1-2$ & 22.8 & 1.9 & 0.25 \\
\hline & $6 "-1-3$ & 30.5 & & \\
\hline & $6 "-1-4$ & & & \\
\hline & $6 "-1-5$ & 27.7 & 1.9 & 0.25 \\
\hline & $6 "-1-6$ & 25.1 & & \\
\hline & $6 "-1-7$ & & & \\
\hline & $6 "-1-8$ & 26.5 & 2.6 & 0.34 \\
\hline & $6 "-1-9$ & 31.8 & 3.0 & 0.39 \\
\hline & & & 4.1 & 0.54 \\
\hline & $6 "-1-11$ & 19.6 & 2.6 & 0.34 \\
\hline & $6 "-1-13$ & 15.3 & & \\
\hline & $6 "-1-16$ & 14.8 & 2.4 & 0.32 \\
\hline \multirow{12}{*}{$\begin{array}{l}\text { Core Sample } \\
3 \mathrm{ftS} \text { - }\end{array}$} & $1-3\left(10^{\prime \prime}\right)$ & 24.4 & 2.9 & 0.38 \\
\hline & $2-2\left(6^{\prime \prime}\right)$ & 86.0 & 1.5 & 0.20 \\
\hline & $2-4\left(10^{\prime \prime}\right)$ & 62.8 & 2.8 & 0.37 \\
\hline & $3-3\left(10^{\prime \prime}\right)$ & 57.5 & 1.0 & 0.13 \\
\hline & $1-2$ & 20.0 & & \\
\hline & 1-5 (valve) & 38.4 & 1.6 & 0.21 \\
\hline & $3-2$ & 47.2 & & \\
\hline & $3-5$ (valve) & 84.3 & 1.4 & 0.18 \\
\hline & 2-6 (valve) & 48.7 & 2.6 & 0.34 \\
\hline & $4-2$ & 63.9 & 1.6 & 0.21 \\
\hline & $4-3$ & 37.1 & & \\
\hline & 4-5 (valve) & 85.3 & 0.5 & 0.06 \\
\hline \multirow[t]{8}{*}{$3 \mathrm{ft} \mathrm{N-}$} & 3-5 (valve) & 34.3 & 1.8 & 0.23 \\
\hline & $4-3$ & 40.6 & 0.8 & 0.10 \\
\hline & 4-5 (valve) & 75.3 & 1.2 & 0.16 \\
\hline & $4-4$ & 39.4 & & \\
\hline & & 16.6 & & \\
\hline & $3-3$ & 41.0 & 1.1 & 0.15 \\
\hline & $3-4$ & 15.7 & & \\
\hline & $4-1$ & 16.2 & & \\
\hline \multirow[t]{2}{*}{$\begin{array}{l}3 \mathrm{ft} \mathrm{N}-15 \text { bottle } \\
\text { sample }\end{array}$} & $1 \mathrm{~B}$ & & 0.9 & 0.12 \\
\hline & $2 \mathrm{~B}$ & & & \\
\hline
\end{tabular}


HNF-1989, REV. 1

\begin{tabular}{|r|r|r|r|r|}
\hline & $3 \mathrm{~B}$ & 28.5 & 2.7 & 0.35 \\
\hline & & & 2.4 & 0.31 \\
\hline & 4 B & 30.2 & & \\
\hline 5 B & 29.0 & 2.9 & 0.38 \\
\hline 6 B & & & \\
\hline & 7 B & 28.0 & 3.0 & 0.40 \\
\hline & 8 B & 25.7 & 10.5 & 1.37 \\
\hline & & & 8.6 & 1.12 \\
\hline & & & 3.0 & 0.39 \\
\hline & 9 B & & & 0.28 \\
\hline & $10 \mathrm{~B}$ & & 2.1 & \\
\hline & $11 \mathrm{~B}$ & & & 0.36 \\
\hline & $12 \mathrm{~B}$ & & 2.8 & 0.24 \\
\hline & $13 \mathrm{~B}$ & 29.8 & & 1.9 \\
\hline
\end{tabular}


HNF-1989, REV. 1

APPENDIX: B

TRANSCRIPTION OF LABORATORY NOTEBOOK DATA RELATED TO TANK 241 Z361 IN ARH-N-400

B-1 
ARH-N-342

Z Plant Process Assistance

D. G. Bouse

\section{4-13-77 241Z361 Tank Core Sampling \& Processing}

A full core sample of 361 Tan $\mathrm{k}$ was taken on 4-12-77. The sample was NDA checked in the field and reported to contain $<20 \mathrm{gm} \mathrm{Pu}$. The sample was place in leach hood- 2 of the $232-Z$ Building (incinerator) and disassembled. The plastic liner of the sampler was full top to bottom. Some free liquid ran out the top of the plastic tubing and was lost to the hood floor. Near the bottom of the sample, the tubing was ruptured with some loss of sample. The bottom of the sample contained some almost white clay like material and was sampled separately as NW-12. Sample 11 was material tat had oozed out of the ruptured plastic and recovered from the hood floor. Samples were sectioned into 5: each of the plastic tubing (the ID was greater than the sample tube after removal) and represented $\sim 6$ : of tank solids/sample. 12 samples were obtained.

Samples were numbered 1 thru 12 from the top surface to the bottom. Samples were placed in tared 1 pint plastic Jars: The samples were individually counted on the $3^{\text {rd }}$ floor 880 sludge counter. 2-30 second counts - the average background for the series. C. Kindel says the net average count/260 yields an approximate $\mathrm{Pu}$ value. Results were:

Sample No. Total Pu g/sample Sample Container Container + sludge g Sludge wt (g) Tare weight $\mathrm{g}$

$\begin{array}{lllll}\text { NW-1 } & 0.065 & 80.750 & 317.800 & 237.050 \\ \text { NW-2 } & 0.096 & 80.390 & 411.100 & 330.710 \\ \text { NW-3 } & 0.115 & 81.260 & 408.000 & 326.740 \\ \text { NW-4 } & 0.073 & 80.750 & 372.900 & 292.150 \\ \text { NW-5 } & 0.173 & 81.290 & 368.800 & 287.510 \\ \text { NW-6 } & 0.065 & 80.660 & 368.500 & 287.840 \\ \text { NW-7 } & 0.127 & 80.560 & 296.000 & 215.440 \\ \text { NW-8 } & 0.050 & 78.810 & 355.100 & 276.290 \\ \text { NW-9 } & 0.123 & 78.860 & 407.900 & 329.040 \\ \text { NW-10 } & 0.085 & 81.930 & 382.900 & 300.970 \\ \text { NW-11 } & 0.038 & 78.750 & 266.000 & 187.250 \\ \text { NW-12 } & 0.058 & 80.480 & 423.500 & 343.020\end{array}$

4-15-77 241-Z-361 Tank (continued)

Efforts to obtain density measurements by placing the sample in a graduated cylinder resulted in unbelievably low spGrs. The method finally used was to tare graduated centrifuge cones, centrifuging a sample of sludge for 10 minutes leaving clear solution on top so the meniscus 
could be read. A description of samples plus the densities were as follows:

Cent. Cent. Sampl Total Solids Sp Gr

Cone, Con eWt Vol Volum $\mathrm{g} / \mathrm{cc}$

Tare Net (g) $(\mathrm{mL}) \quad$ e

Wt.

\begin{tabular}{|c|c|c|c|c|c|c|}
\hline NW-1 & 36.3 & 57.2 & 20.9 & 19.0 & & 1.10 Dark Brown -almost Black - loose -wet \\
\hline NW-2 & 36.6 & 57.2 & 20.6 & 19.0 & & 1.08 Color of Sample 1 - thicker \\
\hline NW-3 & 36.3 & 56.7 & 20.4 & 18.7 & 16.8 & $\begin{array}{l}1.09 \text { small amount of free liquid on top Color of } \\
\text { sample } 1 \text { - thicker than } 2\end{array}$ \\
\hline NW-4 & 36.2 & 56.6 & 20.4 & 17.5 & 15.0 & 1.17 Dark brown -lighter than 2- thinner \\
\hline NW-5 & 36.5 & 56.5 & 20.0 & 16.0 & & $\begin{array}{l}1.25 \text { lighter color than } 4 \text { - very watery - thin } \\
\text { soup }\end{array}$ \\
\hline NW-6 & 36.1 & 56.3 & 20.2 & 17.5 & 14.3 & $\begin{array}{l}1.15 \text { thicker than } 5 \text { - lighter color than } 5 \text { - gritty } \\
\text { - sandy }\end{array}$ \\
\hline NW-7 & 36.0 & 56.6 & 20.6 & 18.2 & 17.5 & $\begin{array}{l}1.13 \text { thicker than } 6 \text { - dark tank color - pasty, } \\
\text { creamy consistency }\end{array}$ \\
\hline NW-8 & 36.0 & 57.0 & 21.0 & 19.8 & 18.5 & 1.06 same a 7 except lighter color \\
\hline NW-9 & 35.9 & 56.9 & 21.0 & 17.5 & 14.2 & $\begin{array}{l}\text { 1.20 Free liquid on top - only slightly darker } \\
\text { color than } 8 \text { - same consistency }\end{array}$ \\
\hline $\begin{array}{l}\text { NW- } \\
10\end{array}$ & 36.2 & 56.7 & 20.5 & 18.5 & 16.5 & 1.11 same as 9 \\
\hline $\begin{array}{l}\text { NW- } \\
11\end{array}$ & 36.1 & 57.4 & 21.3 & 19.0 & 17.0 & 1.12 tan-brown Same at 10 - slightly a darker \\
\hline $\begin{array}{l}\text { NW- } \\
12\end{array}$ & 35.8 & 56.0 & 20.2 & 17.0 & 15.0 & $\begin{array}{l}1.19 \text { lot of liquid on top. Lt brown darker than } \\
5 \text { above samples }\end{array}$ \\
\hline
\end{tabular}

Samples 1-4 Very dark brown - almost black

Sample 5 Lighter dark brown than above

Sample 6 look just like ordinary soil mixed with water

Samples 7-8-9-10 \& 11 light brown to tan color - sample 8 lightest of all - creamy consistency

Sample 12 was darker brown than 7 thru 11 - looks more like sample 6 


\section{4-19-77 241-Z-361 Tank Core Sample Characterization (continued)}

All samples will be filtered, the solids air-dried and the density of the air-dried solids determined. Since there is some sample loss through handling for density measurements, sludge sticking to containers, etc., the sample will be weighed before removing sludge to filter and the sample container reweighed after placing sludge on filter.

\begin{tabular}{|c|c|c|c|c|c|c|c|c|c|c|c|c|}
\hline $\begin{array}{c}\text { Sample } \\
+ \\
\text { Contain } \\
\text { er Wt. } \\
\text { (g) }\end{array}$ & $\begin{array}{c}\text { Empty } \\
\text { Contain } \\
\text { er }\end{array}$ & $\begin{array}{l}\text { Sludge } \\
\text { on Filter }\end{array}$ & $\begin{array}{l}\text { Dried } \\
\text { Solids } \\
\text { (g) }\end{array}$ & $\begin{array}{c}\text { Sludge } \\
\text { on Filte } \\
\text { - Dried } \\
\text { Solids }\end{array}$ & $\begin{array}{l}\text { Assume } \\
d \text { to be } \\
\text { wt of } \\
\text { "trappe } \\
d \text { "liquid }\end{array}$ & $\begin{array}{l}\text { Vol liq } \\
\text { filter/ } \\
\text { vol liq } \\
\text { trappe }\end{array}$ & & & $\begin{array}{l}\text { Liquid } \\
\text { SpG }\end{array}$ & & & $\begin{array}{cc}\text { Using } & \text { Total Pu } \\
\text { Correct } & \text { in Liquid } \\
\text { ed Vol } & \text { (g) }\end{array}$ \\
\hline
\end{tabular}

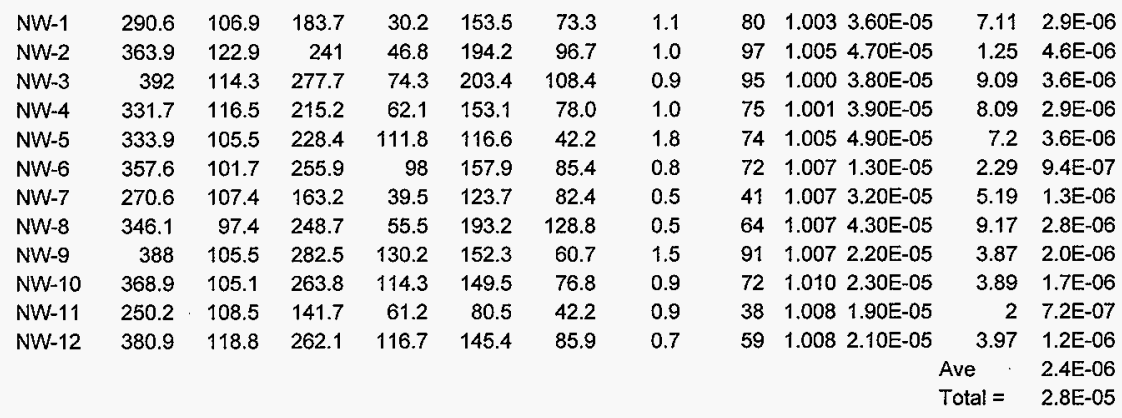

Sample \#5 contained the highest Pu value according to NDA tests. The sample isotopic concentration was determined by gamma counting. Results were as follows:

\begin{tabular}{lr} 
Isotope & \multicolumn{1}{c}{$w \boldsymbol{r} \%$} \\
$238 \mathrm{Pu}$ & 0.00874 \\
$239 \mathrm{Pu}$ & 93.7 \\
$240 \mathrm{Pu}$ & 6.023 \\
$241 \mathrm{Pu}$ & 0.2333 \\
$241 \mathrm{Am}$ & 0.4758
\end{tabular}


The sample weight loss between the sludge and the dry solids has got to be loss of liquid from evaporation. Most liquid comes off rapidly from and was removed frequently from flask, but most of the liquid trapped by solids evaporates as the sample dries and is not accounted for.

$\begin{array}{rrr}1- & 73.3 & 153.5 \\ 2- & 96.7 & 194.2 \\ 3- & 108.4 & 203.4 \\ 4- & 78.0 & 153.1 \\ 5- & 42.2 & 116.6 \\ 6- & 85.4 & 157.9 \\ 7- & 82.4 & 123.7 \\ 8- & 128.8 & 193.2 \\ 9- & 60.7 & 152.3 \\ 10- & 76.8 & 149.5 \\ 11- & 42.2 & 80.5 \\ 12- & 85.9 & 145.4\end{array}$




\section{4-27-77 241-Z-361 Tank Core Sample Characterization (continued)}

After drying (air dried - some require $\sim 48 \mathrm{hrs}$ or over the weekend) the density of the solids was determined by adding $\sim 1 \mathrm{gm}$ of solids to a graduate containing $5 \mathrm{~mL}$ of NPH and the final volume measured. The volume $\%$ solids in the samples were calculated the way Dressen calculated them, i.e.,

$$
\frac{\text { [wt solids }(\mathrm{gm})][\rho \text { sludge] } \times 100}{[w t \text { sludge }(\mathrm{gm})][\rho \text { solids ] }}=\text { vol. } \% \text { solids }
$$

$1 \mathrm{gm}$ sample of the dried solids were fused with $\mathrm{KOH}-\mathrm{Na}_{2} \mathrm{O}_{2}$ for $1 \mathrm{Hour}$. Samples were dissolved in 6-12 $\mathrm{M} \mathrm{HNO}_{3}$. Sample $512 \underline{\mathrm{M}} \mathrm{HNO}_{3}$ - all others $6 \underline{\mathrm{M}} \mathrm{HNO}_{3}$. A sample of NQ-5 will be submitted for $\mathrm{E}$ spec analysis. Portions of the dissolved solids will be sent to 222-S for

\begin{tabular}{|c|c|c|c|c|c|c|c|}
\hline & $\begin{array}{l}\text { Dried } \\
\text { Solids } \\
\text { Density } \\
(\mathrm{g} / \mathrm{L})\end{array}$ & $\begin{array}{l}\text { Solution Vol } \\
(\mathrm{mL})\end{array}$ & $\mathrm{Pu}(\mathrm{g} / \mathrm{L})$ & $\begin{array}{l}\text { Pu total } \\
\text { (mg) }\end{array}$ & $\begin{array}{l}\text { Pu Solids } \\
\text { (g/L) }\end{array}$ & $\begin{array}{l}\text { Volume \% } \\
\text { Solids in } \\
\text { Sample }\end{array}$ & $\begin{array}{l}\text { Dried } \\
\text { Solids wt \% } \\
\text { of total } \\
\text { Sample wt }\end{array}$ \\
\hline$N W-1^{*}$ & 2.08 & 169 & 0.0032 & 0.54 & 1.02 & $8.69 \%$ & $16.4 \%$ \\
\hline NW-2 & 1.86 & 146 & 0.0031 & 0.45 & 0.84 & $11.32 \%$ & $19.4 \%$ \\
\hline NW-3 & 2.17 & 180 & 0.0022 & 0.40 & 0.86 & $13.5 \%$ & $26.8 \%$ \\
\hline NW-4 & 2.50 & 182 & 0.0022 & 0.40 & 1.00 & $13.5 \%$ & $28.9 \%$ \\
\hline NW-5 & 1.69 & 112 & 0.0046 & 0.52 & 0.87 & $36.2 \%$ & $48.9 \%$ \\
\hline NW-6 & 1.63 & 188 & 0.0039 & 0.73 & 1.20 & $27.1 \%$ & $38.3 \%$ \\
\hline NW-7 & 1.79 & 195 & 0.0033 & 0.64 & 1.15 & $15.3 \%$ & $24.2 \%$ \\
\hline NW-8 & 2.17 & 195 & 0.003 & 0.59 & 1.27 & $10.9 \%$ & $22.3 \%$ \\
\hline NW-9 & 1.56 & 138 & 0.0029 & 0.40 & 0.62 & $35.5 \%$ & $46.1 \%$ \\
\hline NW-10 & 1.50 & 183 & 0.0027 & 0.49 & 0.74 & $32.0 \%$ & $43.3 \%$ \\
\hline NW-11 & 1.56 & 155 & 0.0017 & 0.26 & 0.41 & $31.0 \%$ & $43.2 \%$ \\
\hline NW-12 & 1.71 & 210 & 0.0015 & 0.32 & 0.54 & $30.9 \%$ & $44.5 \%$ \\
\hline
\end{tabular}
further analyses. AT will be run by $234-5 \mathrm{lab}$.

Sample NW-1 = $1.1 \mathrm{gm}$ of solids - all other $1 \mathrm{gm}$.

One gm each of the following samples were fused in $\mathrm{KOH}$ only - dissolved in $12 \mathrm{M} \mathrm{HCl}$ and submitted for $\mathrm{Na} \& \mathrm{~N}$ analysis.

NW-3A $-\mathrm{Vol}=206 \mathrm{~mL}$

NW-4A $-\mathrm{Vol}=181 \mathrm{~mL}$

$\mathrm{NW}-5 A-\mathrm{Vol}=193 \mathrm{~mL}$

NW-6A $-\mathrm{Vol}=192 \mathrm{~mL}$

$\mathrm{NW}-7 \mathrm{~A}-\mathrm{Vol}=210 \mathrm{~mL}$

$\mathrm{NW}-9 \mathrm{~A}-\mathrm{Vol}=206 \mathrm{~mL}$ 


\section{5-5-77 241-Z-361 Tank Core Sample Characterization (continued)}

The following details were extracted from previous pages

$\begin{array}{lrrrrrcccc} & 1 & 2 & 3 & 4 & 5 & 6 & 7 & 8 & 9 \\ \text { NW-1 } & 38.97066 & 198.079 & 18.74 & 197.4869 & 7.11 \mathrm{E}-03 & 19.15939 & 1.92 \mathrm{E}+01 & 1.02 & 0.089 \\ \text { NW-2 } & 64.22086 & 266.489 & 34.53 & 265.1633 & 1.25 \mathrm{E}-02 & 29.06636 & 2.91 \mathrm{E}+01 & 0.84 & 0.095 \\ \text { NW-3 } & 87.42089 & 239.319 & 40.29 & 239.3191 & 9.09 \mathrm{E}-03 & 34.61867 & 3.46 \mathrm{E}+01 & 0.86 & 0.116 \\ \text { NW-4 } & 84.30537 & 207.845 & 33.72 & 207.637 & 8.10 \mathrm{E}-03 & 33.75587 & 3.38 \mathrm{E}+01 & 1.00 & 0.135 \\ \text { NW-5 } & 140.7339 & 146.776 & 83.27 & 146.0459 & 7.16 \mathrm{E}-03 & 72.50609 & 7.25 \mathrm{E}+01 & 0.87 & 0.315 \\ \text { NW-6 } & 110.2318 & 177.608 & 67.63 & 176.3736 & 2.29 \mathrm{E}-03 & 80.82196 & 8.08 \mathrm{0}+01 & 1.20 & 0.324 \\ \text { NW-7 } & 52.14387 & 163.296 & 29.13 & 162.161 & 5.19 \mathrm{E}-03 & 33.55458 & 3.36 \mathrm{E}+01 & 1.15 & 0.176 \\ \text { NW-8 } & 61.657 & 214.633 & 28.41 & 213.141 & 9.17 \mathrm{E}-03 & 36.06934 & 3.61 \mathrm{E}+01 & 1.27 & 0.138 \\ \text { NW-9 } & 151.6496 & 177.390 & 97.21 & 176.1573 & 3.88 \mathrm{E}-03 & 60.69016 & 6.07 \mathrm{E}+01 & 0.62 & 0.221 \\ \text { NW-10 } & 130.4051 & 170.565 & 86.94 & 168.8761 & 3.88 \mathrm{E}-03 & 64.43317 & 6.44 \mathrm{E}+01 & 0.74 & 0.237 \\ \text { NW-11 } & 80.87297 & 106.377 & 51.84 & 105.5328 & 2.01 \mathrm{E}-03 & 21.31003 & 2.13 \mathrm{E}+01 & 0.41 & 0.128 \\ \text { NW-12 } & 152.7296 & 190.290 & 89.32 & 188.7801 & 3.96 \mathrm{E}-03 & 48.10983 & 4.81 \mathrm{E}+01 & 0.54 & 0.167\end{array}$

1 - Total solids in sample gm. Initial sample wt $x$ w/o dried solids

2 - Total liquid gm - solids wt minus told sample wt

3 - Total solids volume - $\mathrm{ml}$ Total solids wt/spGr

4 - total volume liquid - $\mathrm{mL}$. Total liquid $\mathrm{wt} / \mathrm{spGr}$.

5 - Total Pu in liquid - $\mathrm{mg}$

6 - Total Pu in sludge - $\mathrm{mg}$

7 - Total $\mathrm{Pu}$ in Sludge - gm - Pu in liquid $+\mathrm{Pu}$ in solids

8 - Pu in solids $\mathrm{g} / \mathrm{L}$

9 - Pu in Sludge g/L 
HNF-1989, REV. 1

APPENDIX: $\mathrm{C}$

TRANSCRIPTION OF LABORATORY NOTEBOOK DATA RELATED TO TANK 241Z361 IN ARH-N-400 
HNF-1989, REV. 1

ARH-N-400

Plutonium Processing Assistance

A. L. Dressen

7-12-76

361-Z Tank Sludge

A request has been received to determine the presence of free liquid in core samples of $361-Z$ sludge. We will examine samples of both the black and brown solids. First we will pour off any supernates and measure the volume. We will then determine if the solids will flow. If they do, we will then filter them and measure the volume of filtrate; the solids may then be dried on a hot plate to measure weight loss. If the solids do not flow, they will be placed in a porcelain filter without paper or vacuum and enough supernate added to make them flow.

7-20-76

Labeling system for $361-Z$ samples:

$$
\begin{aligned}
& 3=3^{\prime \prime} \text { riser } \\
& S=\text { south end of tank } \\
& 1=\# 1 \text { core barrel (from top) } \\
& 1=1^{\text {st }} 6^{11} \text { fraction from top }
\end{aligned}
$$

\section{$\underline{3 S-1-3}$}

No supernate appeared on the sample and the solids would not flow. The solids were black and had the consistency of frosting. The sample was filtered overnight with a vacuum but any liquid drawn off had evaporated by morning.

\section{S-4-3}

Some brown soupy supernate appeared on the sample and $28 \mathrm{~mL}$ flowed through a filter without paper or vacuum. Most of the rest of the solids would slowly flow and were filtered overnight with the sample result as the sample above.

\section{$\underline{7-21-76}$}

3-S-1-2

Appeared like black tar with no supernate and solids would not flow. However, $81 \mathrm{~mL}$ of liquids was pulled thru the filter when vacuum was used. The resulting solids were still quite gummy and $10 \mathrm{~mL}$ of filtrate was required to make $5 \mathrm{~g}$ of the solids flow.

\section{S-4-2}

Brown soup appeared over the solids; $40 \mathrm{~mL}$ of the sample would flow. The material which flowed separated on standing for a24 hours into $25 \mathrm{~mL}$ of still flowable solids and $15 \mathrm{~mL}$ of liquid. The nonflowing solids yielded $52 \mathrm{~mL}$ of liquid when filtered with a vacuum. $10 \mathrm{~mL}$ of the filtrate was required to make $5 \mathrm{~g}$ of the dried solids flow. 


\section{9-15-76}

A core sample of $361-Z$ sludge will be delivered to CTL within a few days. Process has requested the following analyses:

For every other section

Volume percent solids

Density of sample

If sample $s$ readily flowable, measure the weight and volume in a graduated cylinder

If sample is largely solids, with the total sample, add $\sim 1$ gram to cylinder containing $5 \mathrm{~mL} \mathrm{NPH}$ and record the final volume;

Filter the sample and air-dry overnight

Weigh the solids

Density of solids - same as 1.b. above

Pu content of solids

If the solids are black, fuse $\sim 1 \mathrm{~g}$ sample.

If the solids are brown, dissolve $1 \mathrm{~g}$ in $12 \mathrm{M} \mathrm{HNO}_{3}$

Submit the solution for Pu (AT-AEA)

For the section containing the highest Pu concentration from I. Above

Determine the volume percent solids and Pu content for the sections on each side as in I.

Above

Send 3-4 grams of the solid to Merrill Bert, HEDL, for analysis of nitrogen, chlorine, carbon, and oxygen.

Send sample of solids for emission spec. analysis.

Dissolve $\sim 1$ gram in $\mathrm{H}_{2} \mathrm{O}$ in a polypropylene vial and send for atomic absorption for $\mathrm{Na}, \mathrm{Fe} \mathrm{Si}$, Al, Cd.

For the sections containing the next 2 highest $\mathrm{Pu}$ concentration from $\mathrm{l}$. above, run the analyses in $11 . \mathrm{B} ., \mathrm{C} ., \mathrm{D}$.

\section{$9-23-76$}

The $361-Z$ sample taken from the northeast quadrant of the tank was sectioned into 124 " portions. SGSAS found the following:

\section{Section Number Pu Content, g Cumulative Pu content,}

$\begin{array}{lll}\text { NE-1 } & 0.68 & 0.68 \\ \text { NE-2 } & 1.80 & 2.48 \\ \text { NE-3 } & 0.69 & 3.17 \\ \text { NE-4 } & 1.20 & 4.37 \\ \text { NE-5 } & 0.96 & 5.33 \\ \text { NE-6 } & 1.40 & 6.73 \\ \text { NE-7 } & 0.30 & 7.03 \\ \text { NE-8 } & 2.40 & 9.43 \\ \text { NE-9 } & 1.6 & 11.03 \\ \text { NE-10 } & 0.93 & 11.96 \\ \text { NE-11 } & 1.0 & 12.96 \\ \text { NE-12 } & 1.7 & 14.66\end{array}$


We will be working with the even-numbered sections initially.

NE-2:

Color $=$ black

Consistency $=$ like frosting

Sample + container $=349.4 \mathrm{~g}$

container $=123.6 \mathrm{~g}$

sample $=225.8 \mathrm{~g}$

density $=.7 \mathrm{~g} / .5 \mathrm{~mL}=1.4 \mathrm{~g} / \mathrm{cm}^{3}$

NE-3:

color $=$ cream-tan

consistency $=$ creamy, buttery

Sample + container $=510.1 \mathrm{~g}$

container $=109.2 \mathrm{~g}$

sample $=400.9 \mathrm{~g}$

density $=1.3 \mathrm{~g} / .8 \mathrm{~mL}=1.6 \mathrm{~g} / \mathrm{cm}^{3}$

NE-4:

Color $=$ dark brown

Consistency $=$ frosting

Sample + container $=394.4 \mathrm{~g}$

container $=142.8 \mathrm{~g}$

sample $=251.6 \mathrm{~g}$

density $=1.6 \mathrm{~g} / 1 \mathrm{~mL}=1.6 \mathrm{~g} / \mathrm{cm}^{3}$

\section{9-24-76}

NE-2:

solids $=77.5 \mathrm{~g}$ density $=1 \mathrm{~g} / .4 \mathrm{~mL}=2.5 \mathrm{~g} / \mathrm{cm}^{3}$

NE-6:

color $=$ light brown

sample + container $=464.4 \mathrm{~g}$ container $=206.0 \mathrm{~g}$ sample $=258.4 \mathrm{~g}$

density $=1.1 \mathrm{~g} / .7 \mathrm{~mL}=1.6 \mathrm{~g} / \mathrm{cm}^{3}$

NE-6:

sample + container $=432.6 \mathrm{~g}$ container $=183.6 \mathrm{~g}$ sample $=249.0 \mathrm{~g}$

density $=1 \mathrm{~g} / .7 \mathrm{~mL}=1.4 \mathrm{~g} / \mathrm{cm}^{3}$

color $=$ light brown filtrate $=69 \mathrm{~mL}$

NE-10:

Solids $=99.4 \mathrm{~g}$

Density $=1 \mathrm{~g} / .4 \mathrm{~mL}=2.5 \mathrm{~g} / \mathrm{cm}^{3}$ 
NE-12:

sample + container $=231.7 \mathrm{~g}$ container $=131.7 \mathrm{~g}$ sample $=100.0 \mathrm{~g}$

color $=$ medium brown

density $=.9 \mathrm{~g} / .6 \mathrm{~mL}=1.5 \mathrm{~g} / \mathrm{cm}^{3}$ 


\section{$\underline{9-28-76}$}

$\mathrm{NE}-4$ :

Solids $=60.6 \mathrm{~g}$

Density $=.9 \mathrm{~g} / .3 \mathrm{~mL}=3 \mathrm{~g} / \mathrm{cm}^{3} \Rightarrow>12.8$ vol $\%$ solids

NE-6:

Solids $=70.8 \mathrm{~g}$

Density $=.9 \mathrm{~g} / .4 \mathrm{~mL}=2.25 \mathrm{~g} / \mathrm{cm}^{3} \Rightarrow 19.5$ vol $\%$ solids

\section{9-29-76}

NE-8:

Solids $=101.2 \mathrm{~g}$

Density $=1 \mathrm{~g} / .5 \mathrm{~mL}=2 \mathrm{~g} / \mathrm{cm}^{3} \Rightarrow 28.4$ vol $\%$ solids

NE-12:

Solids $=31.1 \mathrm{~g}$

Density $=1 \mathrm{~g} / .4 \mathrm{~mL}=2.5 \mathrm{~g} / \mathrm{cm}^{3} \Rightarrow 18.7 \mathrm{vol} \%$ solids

10-1-76

NE-2 fusion:

Wt sample $=2 \mathrm{~g}$

Soln. Volume $=218 \mathrm{~mL}$

$\mathrm{GPu} / \mathrm{L}=.008$

Wt $\%$ Pu in solids $=.087$

10-4-76

NE-4 fusion:

$W$ sample $=2 \mathrm{~g}$

Soln. Volume $=240 \mathrm{~mL}$ $\mathrm{G} \mathrm{Pu} / \mathrm{L}=.008$

$\mathrm{Wt} \% \mathrm{Pu}$ in solids $=.084$

10-5-76

NE-6 fusion:

$W t$ sample $=2 \mathrm{~g}$

Soln. Volume $=240 \mathrm{~mL}$ $\mathrm{G} P u / L=.007$

$\mathrm{Wt} \% \mathrm{Pu}$ in solids $=.084$

NE-12 fusion:

$W t$ sample $=2 \mathrm{~g}$

Soln. Volume $=297 \mathrm{~mL}$

$\mathrm{G} \mathrm{Pu} / \mathrm{L}=.003$

$\mathrm{Wt} \% \mathrm{Pu}$ in solids $=.044$ 
NE-8 fusion:

Wt sample $=2 \mathrm{~g}$

Soln. Volume $=315 \mathrm{~mL}$

$\mathrm{G} \mathrm{Pu} / \mathrm{L}=.003$

$\mathrm{Wt} \% \mathrm{Pu}$ in solids $=.044$

NE-10 fusion:

Wt sample $=2 \mathrm{~g}$

Soln. Volume $=304 \mathrm{~mL}$

$\mathrm{GPu} / \mathrm{L}=.005$

Wt \% Pu in solids $=.079$

\section{0-11-76}

\begin{tabular}{|l|l|l|l|l|}
\hline Section No. & Vol \% Solids & G Pu/L solids & G Pu/L sludge & $\begin{array}{l}\text { Difference with } \\
\text { SGSAS }\end{array}$ \\
\hline 2 & 19.2 & 2.18 & .42 & $-90.1 \%$ \\
\hline 4 & 12.8 & 3.37 & .43 & $-94.4 \%$ \\
\hline 6 & 19.5 & 1.89 & .37 & $-95.8 \%$ \\
\hline 8 & 28.4 & .89 & .25 & $-89.4 \%$ \\
\hline 10 & 15.8 & 1.97 & .31 & $-66.4 \%$ \\
\hline 12 & 18.7 & 1.11 & .21 & $-87.8 \%$ \\
\hline 3 & 45.6 & .20 & .097 & \\
\hline 5 & 21.8 & .72 & .157 & \\
\hline
\end{tabular}

\section{0-13-76}

\section{NE-3:}

Sludge $w t=263.9$

Density $=2 \mathrm{~g} / 1.3 \mathrm{~mL}=1.5 \mathrm{~g} / \mathrm{mL}$

Filtered overnight $=>$ ? $\mathrm{mL}$ filtrate

NE-5:

Sludge $w t=444.2$

Density $=2 \mathrm{~g} / 1.9 \mathrm{ML}=1.05 \mathrm{~g} / \mathrm{mL}$

Filtered overnight $=>$ ? $\mathrm{mL}$ filtrate

10-18-76

NE-3:

Solids $=134 \mathrm{~g}$ never did dry completely after 4 days

Density $=1 \mathrm{~g} / .6 \mathrm{~mL}=1.67 \mathrm{~g} / \mathrm{cm} 3 \Rightarrow 21.8 \mathrm{vol} \%$ solids

$\mathrm{NE}-3$ fusion $=$

Wt sample $=2 \mathrm{~g}$

Soln. Volume $=240 \mathrm{~mL}$

$\mathrm{G} P u / L=.001$

$\mathrm{Wt} \% \mathrm{Pu}$ in solids $=.012$ 
HNF-1989, REV. 1

NE-5 fusion:

Wt. Sample $=2 \mathrm{~g}$

Soln. Volume $=220 \mathrm{~mL}$

$\mathrm{GPu} / \mathrm{L}=.0024$

Wt $\% \mathrm{Pu}$ in solids $=.026$

10-20-76

Emission spec of NE-4: (ppm)

\begin{tabular}{|l|l|l|}
\hline $\mathrm{Al}=60,000$ & $\mathrm{Ga}<80$ & $\mathrm{Si}=5000$ \\
\hline $\mathrm{B}<10$ & $\mathrm{~K}=3000$ & $\mathrm{Sn}=20$ \\
\hline $\mathrm{Be}<10$ & $\mathrm{Mg}=19,000$ & $\mathrm{Ta}<400$ \\
\hline $\mathrm{Bi}=50$ & $\mathrm{Mn}=400$ & $\mathrm{Ti}=150$ \\
\hline $\mathrm{Cd}=50$ & $\mathrm{Mo}=300$ & $\mathrm{~V}<200$ \\
\hline $\mathrm{Co}=1000$ & $\mathrm{Na}=50,000$ & $\mathrm{~W}=400$ \\
\hline $\mathrm{Cr}=800$ & $\mathrm{Nb}<160$ & $\mathrm{Zn}=5000$ \\
\hline $\mathrm{Cu}=2500$ & $\mathrm{Ni}=2000$ & $\mathrm{Zr}<160$ \\
\hline $\mathrm{Fe}=40,000$ & $\mathrm{~Pb}=200$ & \\
\hline
\end{tabular}


HNF-1989, REV. 1

APPENDIX D:

PLUTONIUM DISCHARGES TO CRIBS Z-1, Z-2, Z-3 AND Z-12 
HNF-1989, REV. 1

\begin{tabular}{|c|c|c|c|c|c|c|c|}
\hline & & \multicolumn{2}{|c|}{$\begin{array}{c}\text { DISCHARGE TO } \\
\text { CRIB }\end{array}$} & \multicolumn{2}{|c|}{ 12-MONTH TOTAL } & \multicolumn{2}{|c|}{ RUNNING TOTAL } \\
\hline Crib & Period & Vol $\left(\times 10^{6} \mathrm{~L}\right)$ & $\begin{array}{l}\text { Plutonium } \\
(\mathrm{g})\end{array}$ & Vol $\left(\times 10^{6} \mathrm{~L}\right)$ & \begin{tabular}{|l|} 
Plutonium \\
(g)
\end{tabular} & Vol $\left(\times 10^{6} \mathrm{~L}\right)$ & $\begin{array}{l}\text { Plutonium } \\
\text { (g) }\end{array}$ \\
\hline$Z-1 \&$ Z-2 & up to June- 52 & 34 & 199 & & & 34 & 199 \\
\hline$Z-1,-2,-3$ & July-52 & 1.635 & 8.2 & & & 35.635 & 207.2 \\
\hline & August-52 & 1.681 & 6.9 & & & 37.316 & 214.1 \\
\hline & September-52 & 1.984 & 5 & & & 39.3 & 219.1 \\
\hline & October-52 & 1.287 & 5.8 & & & 40.587 & 224.9 \\
\hline & November-52 & 1.299 & 12.9 & & & 41.886 & 237.8 \\
\hline & December-52 & 1.327 & 5.9 & 43.213 & 243.7 & 43.213 & 243.7 \\
\hline & January-53 & 1.02 & 6.3 & & & 44.233 & 250 \\
\hline & February-53 & 0.75 & 5.8 & & & 44.983 & 255.8 \\
\hline & March-53 & 0.86 & 4.2 & & & 45.843 & 260 \\
\hline & April-53 & 0.91 & 7.5 & & & 46.753 & 267.5 \\
\hline & May-53 & 0.87 & 9.5 & & & 47.623 & 277 \\
\hline & June-53 & 0.97 & 10 & & & 48.593 & 287 \\
\hline & July-53 & 1.04 & 10.7 & & & 49.633 & 297.7 \\
\hline & August-53 & 0.65 & 5.4 & & & 50.283 & 303.1 \\
\hline & September-53 & 0.82 & 14.9 & & & 51.103 & 318 \\
\hline & October-53 & 1.378 & 8.3 & & & 52.481 & 326.3 \\
\hline & November-53 & 0.67 & 4.4 & & & 53.151 & 330.7 \\
\hline & December-53 & 1.27 & 8.1 & 11.208 & 95.1 & 54.421 & 338.8 \\
\hline & January-54 & 0.89 & 4.3 & & & 55.311 & 343.1 \\
\hline & February-54 & 0.92 & 4.1 & & & 56.231 & 347.2 \\
\hline & March-54 & 1.57 & 10 & & & 57.801 & 357.2 \\
\hline & April-54 & 0.22 & 6.5 & & & 58.021 & 363.7 \\
\hline & May-54 & 1.48 & 17.3 & & & 59.501 & 381 \\
\hline & June-54 & 0.3 & 1.4 & & & 59.801 & 382.4 \\
\hline & July 54 & 0.571 & 11.8 & & & 60.372 & 394.2 \\
\hline & August-54 & 0.921 & 6.72 & & & 61.293 & 400.92 \\
\hline & September-54 & 0.948 & 4.86 & & & 62.241 & 405.78 \\
\hline & October-54 & 1.05 & 7.47 & & & 63.291 & 413.25 \\
\hline & November-54 & 1.21 & 12.6 & & & 64.501 & 425.85 \\
\hline & December-54 & 1.4 & 9.2 & 11.48 & 96.25 & 65.901 & 435.05 \\
\hline
\end{tabular}


HNF-1989, REV. 1

\begin{tabular}{|c|c|c|c|c|c|c|c|}
\hline \multirow{2}{*}{\begin{tabular}{||l} 
\\
Crib
\end{tabular}} & \multirow[b]{2}{*}{ Period } & \multicolumn{2}{|c|}{$\begin{array}{c}\text { DISCHARGE TO } \\
\text { CRIB } \\
\end{array}$} & \multicolumn{2}{|c|}{ 12-MONTH TOTAL } & \multicolumn{2}{|c|}{ RUNNING TOTAL } \\
\hline & & Vol $\left(x 10^{6} \mathrm{~L}\right)$ & $\begin{array}{l}\text { Plutonium } \\
\text { (g) }\end{array}$ & $\operatorname{Vol}\left(x 10^{6} \mathrm{~L}\right)$ & \begin{tabular}{|l|} 
Plutonium \\
$(\mathrm{g})$
\end{tabular} & Vol $\left(x 10^{6} \mathrm{~L}\right)$ & $\begin{array}{l}\text { Plutonium } \\
\text { (g) }\end{array}$ \\
\hline & January-55 & 0.449 & 22.3 & & & 66.35 & 457.35 \\
\hline & February-55 & 0.195 & 15.4 & & & 66.545 & 472.75 \\
\hline & March-55 & 0.354 & 23.2 & & & 66.899 & 495.95 \\
\hline & April-55 & 1.63 & 30.2 & & & 68.529 & 526.15 \\
\hline & May-55 & 2.25 & 37.1 & & & 70.779 & 563.25 \\
\hline & June-55 & 6.49 & 17.9 & & & 77.269 & 581.15 \\
\hline & July-55 & 2.96 & 29.8 & & & 80.229 & 610.95 \\
\hline & August-55 & 4.82 & 32.6 & & & 85.049 & 643.55 \\
\hline & September-55 & 4.72 & 96.1 & & & 89.769 & 739.65 \\
\hline & October-55 & 3.92 & 38.4 & & & 93.689 & 778.05 \\
\hline & November-55 & 1.86 & 56.6 & & & 95.549 & 834.65 \\
\hline & December-55 & 3.64 & 25.5 & 33.288 & 425.1 & 99.189 & 860.15 \\
\hline & January-56 & 1.89 & 16.1 & & & 101.079 & 876.25 \\
\hline & February-56 & 2.13 & 19.2 & & & 103.209 & 895.45 \\
\hline & March-56 & 2.07 & 47.4 & & & 105.279 & 942.85 \\
\hline & April-56 & 3.99 & 38.5 & & & 109.269 & 981.35 \\
\hline & May-56 & 0.969 & 199 & & & 110.238 & 1180.35 \\
\hline & June-56 & 2.07 & 35.9 & & & 112.308 & 1216.25 \\
\hline & July-56 & 1.53 & 41.7 & & & 113.838 & 1257.95 \\
\hline & August-56 & 3.4 & 51.6 & & & 117.238 & 1309.55 \\
\hline & September-56 & 2.51 & 25.5 & & & 119.748 & 1335.05 \\
\hline & October-56 & 2.8 & 119 & & & 122.548 & 1454.05 \\
\hline & November-56 & 2.9 & 50.4 & & & 125.448 & 1504.45 \\
\hline & December-56 & 2.97 & 69.4 & 29.229 & 713.7 & 128.418 & 1573.85 \\
\hline & January-57 & 3.11 & 57.8 & & & 131.528 & 1631.65 \\
\hline & February-57 & 2.18 & 29.6 & & & 133.708 & 1661.25 \\
\hline & March-57 & 3.33 & 42.7 & & & 137.038 & 1703.95 \\
\hline & April-57 & 3.51 & 64 & & & 140.548 & 1767.95 \\
\hline & May-57 & 4.06 & 161 & & & 144.608 & 1928.95 \\
\hline & June-57 & 2.43 & 51.3 & & & 147.038 & 1980.25 \\
\hline & July-57 & 2.76 & 97.7 & & & 149.798 & 2077.95 \\
\hline & August- 57 & 3.38 & 182.7 & & & 153.178 & 2260.65 \\
\hline & September-57 & 3.28 & 47.2 & & & 156.458 & 2307.85 \\
\hline & October-57 & 2.1 & 493 & & & 158.558 & 2800.85 \\
\hline & November-57 & 2.05 & 450.7 & & & 160.608 & 3251.55 \\
\hline & December-57 & 1.98 & 34.5 & 34.17 & 1712.2 & 162.588 & 3286.05 \\
\hline
\end{tabular}


HNF-1989, REV. 1

\begin{tabular}{|c|c|c|c|c|c|c|c|}
\hline \multirow[b]{2}{*}{ Crib } & \multirow[b]{2}{*}{ Period } & \multicolumn{2}{|c|}{$\begin{array}{c}\text { DISCHARGE TO } \\
\text { CRIB }\end{array}$} & \multicolumn{2}{|c|}{ 12-MONTH TOTAL } & \multicolumn{2}{|c|}{ RUNNING TOTAL } \\
\hline & & Vol $\left(\times 10^{6} L\right)$ & $\begin{array}{l}\text { Plutonium } \\
\text { (g) }\end{array}$ & Vol $\left(\times 10^{6} \mathrm{~L}\right)$ & \begin{tabular}{|l|} 
Plutonium \\
$(\mathrm{g})$
\end{tabular} & Vol $\left(\times 10^{6} L\right)$ & $\begin{array}{l}\text { Plutonium } \\
(\mathrm{g})\end{array}$ \\
\hline & June-58 & 17 & 1330 & & & 179.588 & 4616.05 \\
\hline & December-58 & 18 & 858 & 35 & 2188 & 197.588 & 5474.05 \\
\hline & June-59 & 9 & 230 & & & 206.588 & 5704.05 \\
\hline$\overline{Z-12}$ & January-59 & & & & & 206.588 & 5704.05 \\
\hline & February-59 & & & & & 206.588 & 5704.05 \\
\hline & March-59 & 2.42 & 25.5 & & & 209.008 & 5729.55 \\
\hline & April-59 & 3.99 & 63.7 & & & 212.998 & 5793.25 \\
\hline & May-59 & 4.55 & 77.9 & & & 217.548 & 5871.15 \\
\hline & June-59 & 5.9 & 118.6 & & & 223.448 & 5989.75 \\
\hline & July-59 & 5.34 & 37.05 & & & 228.788 & 6026.8 \\
\hline & August-59 & 5.1 & 65.56 & & & 233.888 & 6092.36 \\
\hline & September-59 & 3.44 & 94.22 & & & 237.328 & 6186.58 \\
\hline & October-59 & 2.94 & 179.68 & & & 240.268 & 6366.26 \\
\hline & November-59 & 2.88 & 146.28 & & & 243.148 & 6512.54 \\
\hline & December-59 & 4.26 & 467.13 & 40.82 & 1275.62 & 247.408 & 6979.67 \\
\hline & January -60 & 3.158 & 371.42 & & & 250.566 & 7351.09 \\
\hline & February-60 & 3.402 & 29.04 & & & 253.968 & 7380.13 \\
\hline & March-60 & 3.091 & 60.83 & & & 257.059 & 7440.96 \\
\hline & April-60 & 3.55 & 1102.08 & & & 260.609 & 8543.04 \\
\hline & May-60 & 3.244 & 71.41 & & & 263.853 & 8614.45 \\
\hline & June- 60 & 3.981 & 89.13 & & & 267.834 & 8703.58 \\
\hline & July-60 & 3.174 & 387.29 & & & 271.008 & 9090.87 \\
\hline & August-60 & 4.645 & 59.6 & & & 275.653 & 9150.47 \\
\hline & September-60 & 4.206 & 110.9 & & & 279.859 & 9261.37 \\
\hline & October-60 & 3.113 & 41.6 & & & 282.972 & 9302.97 \\
\hline & November-60 & 4.086 & 95.7 & & & 287.058 & 9398.67 \\
\hline & December-60 & 4.484 & 88.7 & 44.134 & 2507.7 & 291.542 & 9487.37 \\
\hline & January-61 & 4.112 & 92.5 & & & 295.654 & 9579.87 \\
\hline & February-61 & 3.752 & 87 & & & 299.406 & 9666.87 \\
\hline & March-61 & 3.047 & 649.2 & & & 302.453 & 10316.07 \\
\hline & April-61 & 2.926 & 272.5 & & & 305.379 & 10588.57 \\
\hline & May-61 & 2.62 & 194 & & & 307.999 & 10782.57 \\
\hline & June-61 & 4.514 & 192 & & & 312.513 & 10974.57 \\
\hline & July-61 & 2.566 & 443 & & & 315.079 & 11417.57 \\
\hline & August-61 & 3.449 & 238 & & & 318.528 & 11655.57 \\
\hline & September-61 & 3.778 & 121 & & & 322.306 & 11776.57 \\
\hline & October-61 & 3.578 & 86 & & & 325.884 & 11862.57 \\
\hline & November-61 & 2.698 & 851 & & & 328.582 & 12713.57 \\
\hline & December-61 & 3.678 & 366 & 40.718 & 3592.2 & 332.26 & 13079.57 \\
\hline
\end{tabular}




\begin{tabular}{|c|c|c|c|c|c|c|c|}
\hline \multirow[b]{2}{*}{ Crib } & \multirow[b]{2}{*}{ Period } & \multicolumn{2}{|c|}{$\begin{array}{c}\text { DISCHARGE TO } \\
\text { CRIB }\end{array}$} & \multicolumn{2}{|c|}{ 12-MONTH TOTAL } & \multicolumn{2}{|c|}{ RUNNING TOTAL } \\
\hline & & Vol $\left(\times 10^{6} \mathrm{~L}\right)$ & \begin{tabular}{|l|}
$\begin{array}{l}\text { Plutonium } \\
(\mathrm{g})\end{array}$ \\
\end{tabular} & Vol $\left(x^{1} 10^{6} L\right)$ & \begin{tabular}{|l|} 
Plutonium \\
(g)
\end{tabular} & Vol $\left(\times 10^{6} \mathrm{~L}\right)$ & $\begin{array}{l}\text { Plutonium } \\
(\mathrm{g})\end{array}$ \\
\hline & January-62 & 2.64 & 684 & & & 334.9 & 13763.57 \\
\hline & February-62 & 2.23 & 295.3 & & & 337.13 & 14058.87 \\
\hline & March-62 & 2.47 & 60 & & & 339.6 & 14118.87 \\
\hline & April-62 & & & & & 339.6 & 14118.87 \\
\hline & May-62 & 0.64 & 43.2 & & & 340.24 & 14162.07 \\
\hline & June-62 & 3.47 & 113 & & & 343.71 & 14275.07 \\
\hline & July-62 & 2.52 & 118.9 & & & 346.23 & 14393.97 \\
\hline & August-62 & 2.15 & 103 & & & 348.38 & 14496.97 \\
\hline & September-62 & 2.25 & 157 & & & 350.63 & 14653.97 \\
\hline & October-62 & 2.15 & 272 & & & 352.78 & 14925.97 \\
\hline & November-62 & 1.68 & 563 & & & 354.46 & 15488.97 \\
\hline & December-62 & 2.28 & 436 & 24.48 & 2845.4 & 356.74 & 15924.97 \\
\hline & January-63 & 2.71 & 528.6 & & & 359.45 & 16453.57 \\
\hline & February-63 & 2.33 & 336 & & & 361.78 & 16789.57 \\
\hline & March-63 & 2.11 & 383 & & & 363.89 & 17172.57 \\
\hline & April-63 & 2.29 & 226 & & & 366.18 & 17398.57 \\
\hline & May-63 & 1.26 & 266.42 & & & 367.44 & 17664.99 \\
\hline & June-63 & 1.61 & 235 & & & 369.05 & 17899.99 \\
\hline & July-63 & 1.51 & 286 & & & 370.56 & 18185.99 \\
\hline & August-63 & 1.35 & 551 & & & 371.91 & 18736.99 \\
\hline & September-63 & 1.7 & 254 & & & 373.61 & 18990.99 \\
\hline & October-63 & 2.07 & 224 & & & 375.68 & 19214.99 \\
\hline & November-63 & 1.68 & 291 & & & 377.36 & 19505.99 \\
\hline & December-63 & 1.62 & 261 & 22.24 & 3842.02 & 378.98 & 19766.99 \\
\hline & January-64 & 1.97 & 242 & & & 380.95 & 20008.99 \\
\hline & February-64 & 1.16 & 229 & & & 382.11 & 20237.99 \\
\hline & March-64 & 1.43 & 334 & & & 383.54 & 20571.99 \\
\hline & April-64 & 1.24 & 334 & & & 384.78 & 20905.99 \\
\hline & May-64 & 1.36 & 411 & & & 386.14 & 21316.99 \\
\hline & June-64 & 1.62 & 154 & & & 387.76 & 21470.99 \\
\hline & July-64 & 1.43 & 248 & & & 389.19 & 21718.99 \\
\hline & August-64 & 1.53 & 126 & & & 390.72 & 21844.99 \\
\hline & September-64 & 1.38 & 257 & & & 392.1 & 22101.99 \\
\hline & October-64 & 1.58 & 212 & & & 393.68 & 22313.99 \\
\hline & November-64 & 2.07 & 349 & & & 395.75 & 22662.99 \\
\hline & December-64 & 1.69 & 303 & 18.46 & 3199 & 397.44 & 22965.99 \\
\hline
\end{tabular}


HNF-1989, REV. 1

\begin{tabular}{|c|c|c|c|c|c|c|c|}
\hline \multirow{2}{*}{ Crib } & \multirow[b]{2}{*}{ Period } & \multicolumn{2}{|c|}{$\begin{array}{c}\text { DISCHARGE TO } \\
\text { CRIB }\end{array}$} & \multicolumn{2}{|c|}{ 12-MONTH TOTAL } & \multicolumn{2}{|c|}{ RUNNING TOTAL } \\
\hline & & Vol $\left(x 10^{6} L\right)$ & $\begin{array}{l}\text { Plutonium } \\
\text { (g) }\end{array}$ & Vol $\left(\times 10^{6} L\right)$ & $\begin{array}{l}\text { Plutonium } \\
(\mathrm{g})\end{array}$ & $\operatorname{Vol}\left(\times 10^{6} \mathrm{~L}\right)$ & $\begin{array}{l}\text { Plutonium } \\
\text { (g) }\end{array}$ \\
\hline & January-65 & 1.727 & 279 & & & 399.167 & 23244.99 \\
\hline & February-65 & 1.252 & 430 & & & 400.419 & 23674.99 \\
\hline & March-65 & 2.28 & 232 & & & 402.699 & 23906.99 \\
\hline & April-65 & 1.773 & 222 & & & 404.472 & 24128.99 \\
\hline & May-65 & 1.651 & 111 & & & 406.123 & 24239.99 \\
\hline & June-65 & 1.625 & 103 & & & 407.748 & 24342.99 \\
\hline & July-65 & 1.289 & 118 & & & 409.037 & 24460.99 \\
\hline & August-65 & 1.113 & 120 & & & 410.15 & 24580.99 \\
\hline & September-65 & 1.663 & 28 & & & 411.813 & 24608.99 \\
\hline & October-65 & 0.871 & 38 & & & 412.684 & 24646.99 \\
\hline & November-65 & 1 & 86 & & & 413.684 & 24732.99 \\
\hline & December-65 & 0.631 & 97 & 16.875 & 1864 & 414.315 & 24829.99 \\
\hline & January-66 & 1.16 & 53 & & & 415.475 & 24882.99 \\
\hline & February-66 & 1.28 & 143 & & & 416.755 & 25025.99 \\
\hline & March-66 & 1.5 & 98 & & & 418.255 & 25123.99 \\
\hline & Aprii-66 & 1.21 & 121 & & & 419.465 & 25244.99 \\
\hline & May-66 & 1.11 & 38 & & & 420.575 & 25282.99 \\
\hline & June-66 & 0.86 & 13 & & & 421.435 & 25295.99 \\
\hline & July-66 & 0.68 & 97 & & & 422.115 & 25392.99 \\
\hline & August-66 & 0.77 & 24 & & & 422.885 & 25416.99 \\
\hline & September-66 & 1.22 & 23 & & & 424.105 & 25439.99 \\
\hline & October-66 & 1.48 & 26 & & & 425.585 & 25465.99 \\
\hline & November-66 & 1.43 & 58 & & & 427.015 & 25523.99 \\
\hline & December-66 & 2.05 & 73 & 14.75 & 767 & 429.065 & 25596.99 \\
\hline & January- 67 & 1.23 & 71 & & & 430.295 & 25667.99 \\
\hline & February-67 & 1.19 & 167 & & & 431.485 & 25834.99 \\
\hline & March-67 & 1.04 & 102 & & & 432.525 & 25936.99 \\
\hline & April-67 & 1.16 & 124 & & & 433.685 & 26060.99 \\
\hline & May-67 & 0.94 & 111 & & & 434.625 & 26171.99 \\
\hline & June-67 & 1.09 & 145 & & & 435.715 & 26316.99 \\
\hline & July-67 & 1.03 & 46 & & & 436.745 & 26362.99 \\
\hline & August- 67 & 1.01 & 124 & & & 437.755 & 26486.99 \\
\hline & September-67 & 0.959 & 38 & & & 438.714 & 26524.99 \\
\hline & October-67 & 0.798 & 25 & & & 439.512 & 26549.99 \\
\hline & November-67 & 0.764 & 52 & & & 440.276 & 26601.99 \\
\hline & December-67 & 0.478 & 30 & 11.689 & 1035 & 440.754 & 26631.99 \\
\hline
\end{tabular}


HNF-1989, REV. 1

\begin{tabular}{|c|c|c|c|c|c|c|c|}
\hline \multirow[b]{2}{*}{ Crib } & \multirow[b]{2}{*}{ Period } & \multicolumn{2}{|c|}{$\begin{array}{c}\text { DISCHARGE TO } \\
\text { CRIB }\end{array}$} & \multicolumn{2}{|c|}{ 12-MONTH TOTAL } & \multicolumn{2}{|c|}{ RUNNING TOTAL } \\
\hline & & Vol $\left(\times 10^{6} \mathrm{~L}\right)$ & $\begin{array}{l}\text { Plutonium } \\
\text { (g) }\end{array}$ & Vol $\left(\times 10^{6} \mathrm{~L}\right)$ & 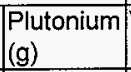 & $\operatorname{Vol}\left(\times 10^{6} \mathrm{~L}\right)$ & \begin{tabular}{|l|} 
Plutonium \\
$(\mathrm{g})$
\end{tabular} \\
\hline & January-68 & 0.483 & 133 & & & 441.237 & 26764.99 \\
\hline & February-68 & 0.504 & 62 & & & 441.741 & 26826.99 \\
\hline & March-68 & 0.469 & 49 & & & $442: 21$ & 26875.99 \\
\hline & April-68 & 0.526 & 48 & & & 442.736 & 26923.99 \\
\hline & May-68 & 0.689 & 58 & & & 443.425 & 26981.99 \\
\hline & June-68 & 0.772 & 43 & & & 444.197 & 27024.99 \\
\hline & July-68 & 0.246 & 34 & & & 444.443 & 27058.99 \\
\hline & August- 68 & 0.57 & 32 & & & 445.013 & 27090.99 \\
\hline & September-68 & 0.213 & 46 & & & 445.226 & 27136.99 \\
\hline & October- 68 & 0.338 & 43 & & & 445.564 & 27179.99 \\
\hline & November-68 & 0.53 & 101 & & & 446.094 & 27280.99 \\
\hline & December-68 & 0.53 & 31 & 5.87 & 680 & 446.624 & 27311.99 \\
\hline & January-69 & 0.242 & 27 & & & 446.866 & 27338.99 \\
\hline & February-69 & 0.151 & 2 & & & 447.017 & 27340.99 \\
\hline & March-69 & 0.738 & 14 & & & 447.755 & 27354.99 \\
\hline & April-69 & 0.515 & 31.8 & & & 448.27 & 27386.79 \\
\hline & May-69 & 0.806 & 78 & & & 449.076 & 27464.79 \\
\hline & June-69 & 0.485 & 77.5 & & & 449.561 & 27542.29 \\
\hline & July-69 & 0.363 & 43.8 & & & 449.924 & 27586.09 \\
\hline & August -69 & 0.522 & 21.8 & & & 450.446 & 27607.89 \\
\hline & September-69 & 0.651 & 37.3 & & & 451.097 & 27645.19 \\
\hline & October-69 & 0.651 & 70 & & & 451.748 & 27715.19 \\
\hline & November-69 & 0.522 & 51.4 & & & 452.27 & 27766.59 \\
\hline & December-69 & 0.784 & 62.5 & 6.43 & 517.1 & 453.054 & 27829.09 \\
\hline & January-70 & 0.348 & 64.6 & & & 453.402 & 27893.69 \\
\hline & February-70 & 0.344 & 54.3 & & & 453.746 & 27947.99 \\
\hline & March-70 & 0.356 & 48 & & & 454.102 & 27995.99 \\
\hline & April-70 & 0.428 & 15.8 & & & 454.53 & 28011.79 \\
\hline & May-70 & 0.121 & 24.7 & & & 454.651 & 28036.49 \\
\hline & June-70 & 0.132 & 28.2 & & & 454.783 & 28064.69 \\
\hline & July-70 & 0.204 & 19.5 & & & 454.987 & 28084.19 \\
\hline & August-70 & 0.182 & 38.5 & & & 455.169 & 28122.69 \\
\hline & September-70 & 0.299 & 57.5 & & & 455.468 & 28180.19 \\
\hline & October-70 & 0.371 & 107.2 & & & 455.839 & 28287.39 \\
\hline & November-70 & 0.466 & 88.7 & & & 456.305 & 28376.09 \\
\hline & December-70 & 0.197 & 103 & 3.448 & 650 & 456.502 & 28479.09 \\
\hline
\end{tabular}




\begin{tabular}{|c|c|c|c|c|c|c|c|}
\hline \multirow{2}{*}{\begin{tabular}{||l||} 
\\
Crib
\end{tabular}} & \multirow[b]{2}{*}{ Period } & \multicolumn{2}{|c|}{$\begin{array}{l}\text { DISCHARGE TO } \\
\text { CRIB }\end{array}$} & \multicolumn{2}{|c|}{ 12-MONTH TOTAL } & \multicolumn{2}{|c|}{ RUNNING TOTAL } \\
\hline & & $\mathrm{Vol}\left(\times 10^{6} \mathrm{~L}\right)$ & $\begin{array}{l}\text { Plutonium } \\
\text { (g) }\end{array}$ & Vol $\left(\times 10^{6} \mathrm{~L}\right)$ & \begin{tabular}{|l|}
$\begin{array}{l}\text { Plutonium } \\
\text { (g) }\end{array}$ \\
\end{tabular} & Vol $\left(\times 10^{6} \mathrm{~L}\right)$ & \begin{tabular}{|l} 
Plutonium \\
(g)
\end{tabular} \\
\hline & January-71 & 0.216 & 54 & & & 456.718 & 28533.09 \\
\hline & February-71 & 0.181 & 66.81 & & & 456.899 & 28599.9 \\
\hline & March-71 & 0.286 & 88.36 & & & 457.185 & 28688.26 \\
\hline & April-71 & 0.659 & 136.4 & & & 457.844 & 28824.66 \\
\hline & May-71 & 0.739 & 152 & & & 458.583 & 28976.66 \\
\hline & June-71 & 0.95 & 102 & & & 459.533 & 29078.66 \\
\hline & July-71 & 0.713 & 87.93 & & & 460.246 & 29166.59 \\
\hline & August-71 & 0.872 & 94.9 & & & 461.118 & 29261.49 \\
\hline & September-71 & 0.87 & 139.1 & & & 461.988 & 29400.59 \\
\hline & October-71 & 0.768 & 33.08 & & & 462.756 & 29433.67 \\
\hline & November-71 & 0.863 & 68.89 & & & 463.619 & 29502.56 \\
\hline & December-71 & 1.067 & 43.11 & 8.184 & 1066.58 & 464.686 & 29545.67 \\
\hline & January-72 & 1.17 & 94 & & & 465.856 & 29639.67 \\
\hline & February-72 & 0.791 & 40 & & & 466.647 & 29679.67 \\
\hline & March-72 & 0.898 & 49 & & & 467.545 & 29728.67 \\
\hline & April-72 & 1.21 & 76 & & & 468.755 & 29804.67 \\
\hline & May-72 & 1.4 & 230 & & & 470.155 & 30034.67 \\
\hline & June-72 & 1.16 & 86.9 & & & 471.315 & 30121.57 \\
\hline & July-72 & 0.762 & 94 & & & 472.077 & 30215.57 \\
\hline & August-72 & 1.24 & 81 & & & 473.317 & 30296.57 \\
\hline & September-72 & 0.867 & 16 & & & 474.184 & 30312.57 \\
\hline & October-72 & 0.689 & 33 & & & 474.873 & 30345.57 \\
\hline & November-72 & 0.784 & 76 & & & 475.657 & 30421.57 \\
\hline & December-72 & 0.713 & 63 & 11.684 & 938.9 & 476.37 & 30484.57 \\
\hline & January-73 & 0.571 & 42 & & & 476.941 & 30526.57 \\
\hline & February-73 & 0.752 & 52 & & & 477.693 & 30578.57 \\
\hline & March-73 & 1.22 & 62 & & & 478.913 & 30640.57 \\
\hline & April-73 & 0.82 & 88 & & & 479.733 & 30728.57 \\
\hline & May-73 & 0.101 & 83 & 3.464 & 327 & 479.834 & 30811.57 \\
\hline
\end{tabular}


Figure 4. Plutonium discharged in waste through 241-Z-361 settling tank from 1949 to 1953.

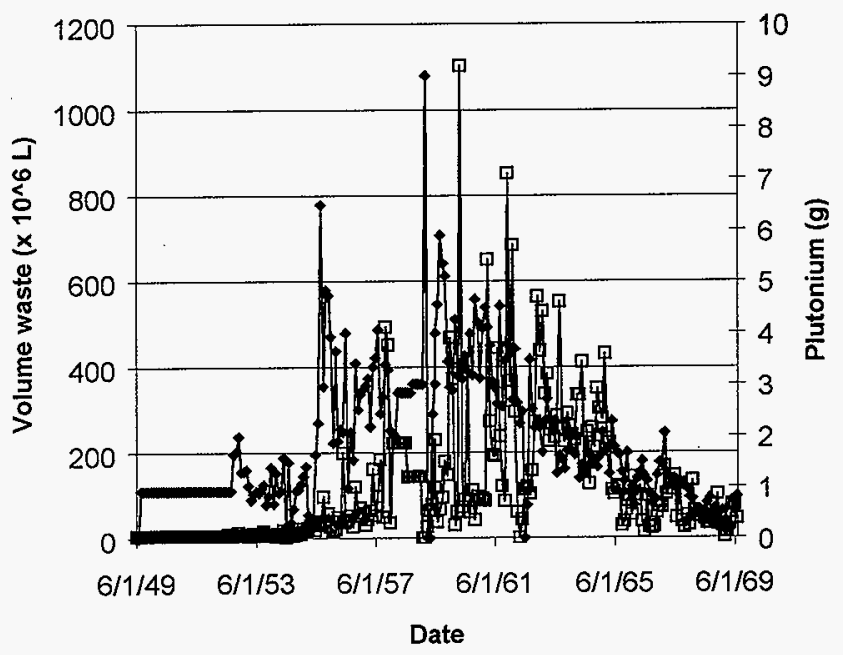

$\rightarrow$ Plutonium Discharge $(g) \rightarrow-$ Volume Discharge $\left(x 10^{\wedge} 6 \mathrm{~L}\right)$ 


\section{DISTRIBUTION SHEET}

\begin{tabular}{|c|c|c|c|c|c|}
\hline \multirow{2}{*}{$\begin{array}{l}\text { To } \\
\text { Distribution }\end{array}$} & \multirow{2}{*}{\multicolumn{3}{|c|}{$\begin{array}{l}\text { From } \\
\text { Plutonium Process Support } \\
\text { Laboratories }\end{array}$}} & \multicolumn{2}{|l|}{ Page 1 of 1} \\
\hline & & & & \multicolumn{2}{|c|}{ Date $06 / 24 / 98$} \\
\hline \multicolumn{4}{|l|}{ Project Title/Work Order } & \multicolumn{2}{|c|}{ EDT No. 612477 e enp } \\
\hline \multicolumn{4}{|c|}{$\begin{array}{l}\text { HNF-1989, Rev. 1, "Tank } 241-Z-361 \text { Process and Characterization } \\
\text { History"/K6215 }\end{array}$} & ECN No. N/A & 629415 \\
\hline Name & MSIN & $\begin{array}{l}\text { Text } \\
\text { With All } \\
\text { Attach. }\end{array}$ & Text Only & $\begin{array}{l}\text { Attach./ } \\
\text { Appendix } \\
\text { Only }\end{array}$ & $\begin{array}{l}\text { EDT/ECN } \\
\text { Only }\end{array}$ \\
\hline
\end{tabular}

B\&W Hanford Company

G. S. Barney

D. M. Bogen

J. E. Bramson

S. A. Jones

A. L. Ramble
T5-12

T5-50

T5-54

T5-12

T5-54 $x$
$x$
$x$
$x$
$x$

R3 -79

R3-79

B5-01

B4-47

B4-46

R2-12

S7-07

R2-12

S7-12

$X$
$X$

Fluor Daniel Hanford

A. M. Hopkins

Fluor Daniel Northwest

B. W. Hall

J. E. Shapley

Lockheed Martin Hanford, Corp.

D. L. Banning

C. Defigh-Price

J. G. FieTd

J. S. Schofield

Lockheed Martin Services, Inc.

Central Fjles

BI-07

$x$

SGN Eurisys Services Corporation

K. V. Scott

R. S. Viswanath

S7-12

S3-90

$x$
$X$

Waste Management Federal Services of Hanford

J. S. $\mathrm{Hill}$

$x$
$x$
$x$
$x$

